\title{
Modelling Sporadic Alzheimer's Disease Using Induced Pluripotent Stem Cells
}

\author{
Helen A. Rowland ${ }^{1} \cdot$ Nigel M. Hooper $^{1} \cdot$ Katherine A. B. Kellett $^{1} \odot$
}

Received: 1 June 2018 / Revised: 11 September 2018 / Accepted: 15 October 2018 / Published online: 1 November 2018

(c) The Author(s) 2018

\begin{abstract}
Developing cellular models of sporadic Alzheimer's disease (sAD) is challenging due to the unknown initiator of disease onset and the slow disease progression that takes many years to develop in vivo. The use of human induced pluripotent stem cells (iPSCs) has revolutionised the opportunities to model AD pathology, investigate disease mechanisms and screen potential drugs. The majority of this work has, however, used cells derived from patients with familial AD (fAD) where specific genetic mutations drive disease onset. While these provide excellent models to investigate the downstream pathways involved in neuronal toxicity and ultimately neuronal death that leads to $\mathrm{AD}$, they provide little insight into the causes and mechanisms driving the development of SAD. In this review we compare the data obtained from $\mathrm{ADD}$ and SAD iPSC-derived cell lines, identify the inconsistencies that exist in SAD models and highlight the potential role of A $\beta$ clearance mechanisms, a relatively under-investigated area in iPSC-derived models, in the study of AD. We discuss the development of more physiologically relevant models using co-culture and three-dimensional culture of iPSC-derived neurons with glial cells. Finally, we evaluate whether we can develop better, more consistent models for SAD research using genetic stratification of iPSCs and identification of genetic and environmental risk factors that could be used to initiate disease onset for modelling sAD. These considerations provide exciting opportunities to develop more relevant iPSC models of SAD which can help drive our understanding of disease mechanisms and identify new therapeutic targets.
\end{abstract}

Keywords Sporadic Alzheimer's disease $\cdot$ Induced pluripotent stem cells $\cdot$ Neurons · Glial cells · Genetic stratification · Environmental risk factors

\section{Introduction}

The potential of using human neurons derived from induced pluripotent stem cells (iPSCs) for in vitro studies has revolutionised research of dementia and other neurodegenerative diseases as many of the challenges that are posed from studying complex disease pathways in the brain could potentially be unravelled in a cell-culture dish. The number of people with Alzheimer's disease (AD), the most common form of dementia, is increasing rapidly within our ageing population. While progress has been made in the understanding of disease pathogenesis, we still do not have any disease modifying treatments. Access to human neurons derived

Katherine A. B. Kellett

katherine.kellett@manchester.ac.uk

1 Division of Neuroscience \& Experimental Psychology, School of Biological Sciences, Faculty of Biology Medicine and Health, University of Manchester, Manchester, UK from iPSCs provide a significant advantage for translational research but these models still need to be refined for us to be able to model the more complex facets of AD.

$\mathrm{AD}$ is characterised by amyloid plaques, composed of amyloid- $\beta(\mathrm{A} \beta)$, and neurofibrillary tangles (NFTs), composed of hyperphosphorylated and truncated tau, in the brain. The amyloid cascade hypothesis, proposed in 1992 [1], whereby the production of $A \beta$ from the sequential $\beta$ - and $\gamma$-secretase cleavage of the amyloid precursor protein (APP) drives disease progression resulting in the formation of NFTs and ultimately toxicity and neuronal cell death, remains the principal hypothesis for investigation [2]. Much of the published evidence supporting this hypothesis comes from studies investigating changes that occur due to increased $A \beta$ production as a result of mutations in either APP or in presenilin 1 (PSEN-1) or PSEN2 , components of the $\gamma$-secretase complex, that occur in familial $A D$ (fAD). In fAD these mutations drive disease progression due to increased $A \beta$ load, but while these 
mutations have provided a useful research tool, particularly in the development of transgenic animal models, it is becoming more evident that the disease mechanisms driving sporadic AD (SAD) [3] which accounts for $>95 \%$ of all AD cases, may be due to more subtle alterations in multiple pathways.

The genetics of SAD have been widely investigated and a number of genes have been indicated as potential risk factors for disease development. The presence of the $\varepsilon 4$ isoform of Apolipoprotein $\mathrm{E}$ ( $A P O E$ ) remains the most significant risk factor for developing $\mathrm{SAD}$ with those heterozygous for the $\varepsilon 4$ allele having an approximately fourfold increased risk of developing AD, while those homozygous for $\varepsilon 4$ have an approximately 12 -fold increased risk [4]. More recently, triggering receptor expressed on myeloid cells 2 (TREM2) has been identified by wholegenome sequencing as another significant risk factor, with loss of function mutations in TREM2 suggested to cause a 2-3 fold increased risk of developing sAD [5, 6]. While $A P O E$ and TREM2 variants could be considered high-risk genes, several other low-risk genes have been identified by genome-wide association studies (GWAS) (extensively reviewed by Raghavan and Tosto [7]). The advent of GWAS studies was predicted to reveal the components of genetic risk in SAD and bring about a new understanding of the disease. However, while a number of genes were identified and validated in separate GWAS studies, their contribution to the overall development of disease pathology is still not fully understood. Interestingly, however, as a number of these genes, including APOE and TREM2, are involved in multiple key pathways linked to SAD, it suggests that understanding the genetics of AD may enable us to significantly progress our understanding of an individual's risk of developing the disease.

With the advent of iPSC technology to produce human neurons there has been a number of studies using iPSCderived neurons to investigate AD. Along with this has come a wealth of review articles to compare differentiation protocols, discuss disease modelling and review evidence from different research studies. The field is advancing rapidly but with the majority of these primary research studies describing models derived from patients with familial mutations, it still appears that we are a long way from really understanding the more complex sAD. In this review we will first discuss the existing studies using iPSC-derived stem cell models and compare those using cells derived from fAD patients to studies using cells derived from control individuals or SAD patients. Second, we will acknowledge the limitations of iPSC-derived models and discuss the progress that is needed to build better research models. Finally, we will address whether further genetic stratification and/or the introduction of environmental risk factors may enable us to realistically study SAD in iPSC-derived cellular models.

\section{Investigating SAD Using iPSC-Derived Neurons}

To date, most AD models using iPSC-derived neurons have focused on familial forms of AD (fAD), the progress and outcomes of which have recently been well reviewed [8]. These studies, using functional, electrophysiologically active neurons, have predominantly used iPSCs from patients diagnosed with $\mathrm{AD}$ with either $\mathrm{fAD}$ mutations in $A P P$ or $P S E N 1$, or from patients with Down's syndrome where the duplication of the $A P P$ gene results in increased $\mathrm{A} \beta$ driving early-onset $\mathrm{AD}$. All studies have, so far, shown an increase in $A \beta$; either in total $A \beta$ or, more specifically in $A \beta 42$ only, resulting in an increase of the $A \beta 42: 40$ ratio. An increase in the aggregation-prone $\mathrm{A} \beta 42$, and in the A $\beta 42: 40$ ratio, accelerates the disease through the production of toxic, oligomeric $A \beta$ species and the formation of amyloid plaques. Other changes have also been observed in these studies including an increase in or altered processing and localisation of APP, an increase in tau and tau phosphorylation, and the activation of GSK $3 \beta$, a physiological kinase of tau. In this section we review the current studies using iPSC-derived neurons from SAD patients and discuss their findings in terms of future modelling of sAD.

\section{$A \beta$ Production in SAD}

The proteolytic processing of APP has been shown to change over time in iPSC-derived neurons. In cortical neurons, $\beta$-secretase cleavage of APP was not apparent until deep-layer (TBR1-positive) neurons were present in culture, with the expression of the $\beta$-secretase ( $\beta$-site APP cleaving enzyme-1; BACE1) also increasing. This is in contrast to the $\alpha$-secretase, responsible for the nonamyloidogenic processing of APP, which was present in the neural progenitor stage of development and throughout neuronal maturation, although with a tendency to decrease after day 60 [9]. This highlights the importance of using cultures of appropriate maturity for investigating disease pathways. It should also be noted that selection of cellular subtypes are important in model selection as neurons directed to a rostral, cortical fate are more sensitive to $A \beta$ than neurons directed to a caudal, hindbrain/spinal cord fate. This may not be surprising as the rostral, cortical neurons are known to be affected during $\mathrm{AD}$ whereas those of a caudal fate are relatively spared in the disease [10].

Limited studies have utilised iPSCs from patients with sAD. Initial studies looked to compare the levels of $A \beta$ between neurons derived from SAD and fAD patient lines and compare these results to controls $[3,11]$. The results of these, and later studies have demonstrated, in 
iPSC-derived neurons, increased $A \beta$ levels $[3,11]$, altered A $\beta 42: 40$ ratios [12] and increased APP expression [12] in sAD patients compared to matched controls, consistent with that seen in fAD models. However, this work also revealed that these changes are not consistent in all sAD patients $[3,11]$. As alluded to in the introduction, sAD is a complex disease with activation of a number of key disease pathways and a multitude of potential risk factors, both genetic and environmental, so it is not surprising that there is a lack of consistency between cell lines derived from different patients. While the genetics driving fAD cause early onset $\mathrm{AD}$ when patients are $<60$ years old, the genetic risk factors identified in SAD patients lead to a later age of onset $\mathrm{AD}$ (late onset $\mathrm{AD}, \mathrm{LOAD}$ ). These genetic risk factors, which will be discussed in further detail in "Genetic Stratification for sAD" and "Environmental and Genetic Risk Factors" sections, do not drive disease progression in the same way as in $\mathrm{AAD}$, and it is likely to be a combination of genetic and environmental risk factors that leads to the development of sAD. For the purpose of this review, we will discuss studies undertaken on iPSCs derived from sAD and LOAD patients under the term SAD; we have included further details of all studies, including details of the cell lines used, and their effects in Table 1 for clarification.

\section{$A \beta$ Degradation in SAD}

While the majority of studies using iPSC-derived neurons have focussed on increased $\mathrm{A} \beta$ production, few, if any, have considered the impact of changes in $A \beta$ clearance for modelling AD. Previous work has demonstrated, in a study of the CNS of cognitively normal compared to SAD patients, that there was no difference in the production of either $A \beta 40$ or $A \beta 42$. What was identified, however, was a significant impairment of $\mathrm{A} \beta$ clearance in those with $\mathrm{AD}$ [13]. The

Table 1 iPSC models from patients with sporadic AD

\begin{tabular}{|c|c|c|c|c|c|c|}
\hline sAD line & Cell type(s) & Phenotype(s) & $\begin{array}{l}\text { Disease APOE } \\
\text { genotype }\end{array}$ & $\begin{array}{l}\text { Additional culture } \\
\text { conditions }\end{array}$ & $\begin{array}{l}\text { Environmental or } \\
\text { genetic risk factor }\end{array}$ & $\begin{array}{l}\text { Experimental } \\
\text { results }\end{array}$ \\
\hline Balez et al. [154] & Neurons & $\uparrow \mathrm{A} \beta 42$ & & & $\mathrm{H}_{2} \mathrm{O}_{2}, \mathrm{NO}$ & $\begin{array}{l}\uparrow \text { neurite retraction, } \\
\text { apoptosis, hyper- } \\
\text { excitable } \mathrm{Ca}^{2+} \\
\text { signalling }\end{array}$ \\
\hline $\begin{array}{l}\text { Birnbaum et al. } \\
\text { [29] }\end{array}$ & Neurons (iN) & $\begin{array}{l}\uparrow \begin{array}{l}\text { ROS }, \uparrow \text { DNA } \\
\text { damage }\end{array} \\
\text { dama }\end{array}$ & $\mathrm{E} 3 / \mathrm{E} 3, \mathrm{E} 3 / \mathrm{E} 4$ & & & \\
\hline Chen et al. [86] & Neurons & & & 3D neuro-spheroid & & $\begin{array}{l}\text { Neuronal dysfunc- } \\
\text { tion similar to AD } \\
\text { brain tissue }\end{array}$ \\
\hline Duan et al. [123] & BFCNs & $\uparrow \mathrm{A} \beta 42: 40$ & E3/E4 & & $\begin{array}{l}\text { Ionomycin, } \\
\text { L-glutamate }\end{array}$ & $\uparrow$ excitotoxicity \\
\hline Hossini et al. [28] & Neurons & $\uparrow$ GSK3 $\beta$ & & & & \\
\hline Israel et al. [11] & Neurons & $\begin{array}{l}\uparrow \mathrm{A} \beta 40, \uparrow \mathrm{p}-\mathrm{tau}, \uparrow \\
\mathrm{GSK}^{2} \beta^{\mathrm{a}}\end{array}$ & E3/E3 & $\begin{array}{c}+ \text { Human astro- } \\
\text { cytes (Lonza) }\end{array}$ & & $\begin{array}{l}\uparrow \text { very large early } \\
\text { endosomes }\end{array}$ \\
\hline Jones et al. [55] & Astrocytes & $\begin{array}{l}\text { Altered S100ß, } \\
\text { EAAT1, GS } \\
\text { and inflamma- } \\
\text { tory mediators } \\
\text { expression and } \\
\text { localisation }\end{array}$ & $\mathrm{E} 4 / \mathrm{E} 4$ & & & \\
\hline Kondo et al. [33] & $\begin{array}{l}\text { Neurons, Astro- } \\
\text { cytes }\end{array}$ & $\begin{array}{c}\uparrow \text { ER stress, } \uparrow \text { OS, } \\
\uparrow \mathrm{A} \beta \text { oligomers }\end{array}$ & & $\begin{array}{l}+ \text { astrocytes of } \\
\text { same iPSC line }\end{array}$ & & $\begin{array}{l}\uparrow \operatorname{ROS} \uparrow \mathrm{A} \beta \text { oli- } \\
\text { gomers }\end{array}$ \\
\hline Lee et al. [85] & Neurons & & & 3D neuro-spheroid & & \\
\hline Lin et al. [56] & $\begin{array}{l}\text { Neurons } \\
\text { Astrocyte } \\
\text { Microglia-like }\end{array}$ & $\begin{array}{l}\downarrow \mathrm{A} \beta \text { uptake }, \uparrow \\
\mathrm{A} \beta 42\end{array}$ & $\mathrm{E} 4 / \mathrm{E} 4, \mathrm{E} 3 / \mathrm{E} 3$ & Organoids & & $\uparrow \mathrm{p}$-tau \\
\hline Ochalek et al. [12] & Neurons & $\begin{array}{l}\uparrow \mathrm{A} \beta 42: 40, \uparrow \mathrm{APP}, \\
\uparrow \mathrm{GSK} 3 \beta, \uparrow \\
\mathrm{p} \text {-tau }\end{array}$ & & & $\begin{array}{l}\mathrm{A} \beta \text { oligomers, } \\
\mathrm{H}_{2} \mathrm{O}_{2}\end{array}$ & $\uparrow$ sensitivity to OS \\
\hline Young et al. [30] & Neurons & & & & SORL1 & \\
\hline Balez et al. [154] & NSCs & $\downarrow$ SORL1 & $\mathrm{E} 4 / \mathrm{E} 4$ & & & \\
\hline
\end{tabular}

$B F C N$ s basal forebrain cholinergic neurons, ER endoplasmic reticulum, NSC neural stem cells, $O S$ oxidative stress, $R O S$ reactive oxygen species ${ }^{\text {a }}$ Phenotypes not observed in all sAD lines in study 
clearance of $A \beta$ occurs in several different ways: the interstitial fluid (ISF) drainage pathway, microglial and macrophage phagocytosis, transcytosis across the blood-brain barrier (BBB), autophagy and proteolytic degradation. All of these pathways have been implicated in SAD and therefore warrant further investigation in iPSC-derived patient cells to determine how they may contribute in the development of SAD [14].

Neuronal $A \beta$ degradation is primarily brought about through proteolytic degradation and autophagy. Several proteases have been recognised for their ability to degrade $\mathrm{A} \beta$, a large number of which are metalloendopeptidases, including neprilysin (NEP) and insulin degrading enzyme (IDE) which appear to be the largest contributors [15]. Clearance and degradation of $A \beta$ by autophagy is disrupted in $A D$ causing increased intracellular $A \beta$ which can be toxic to neurons $[16,17]$. Neurons may, however, have a relatively small role to play in terms of $A \beta$ clearance compared to surrounding glial cells. The contribution of enzymatic degradation by astrocytes may be a major contributing factor and there is evidence to suggest that APOE, the most significant genetic risk factor for $\mathrm{SAD}$, affects proteolytic degradation of $\mathrm{A} \beta$ by astrocytes via NEP and IDE [18, 19]. Of the other pathways mentioned, $A \beta$ clearance via the ISF drainage pathway may play a larger role than previously considered [20] and clearance through the $\mathrm{BBB}$, mediated by $\mathrm{A} \beta$ chaperone proteins, is disrupted in $\mathrm{AD}$ [21]. Both of these pathways link to known genetic risk factors of LOAD and indicate additional avenues for investigation requiring modelling of the BBB as part of the neurovascular unit (NVU) which is the interface between the neural and vascular cells. The role of glia and other cell types in the brain and CNS and their potential role in the development of $\mathrm{AD}$ will be discussed further in "Building Better Models for sAD" section and the implications of genetic risk factors for SAD will be discussed in "Genetic Stratification for sAD" section.

\section{Tau Pathology in SAD}

iPSC-derived neurons from fAD cell lines over-expressing APP (cell lines from patients with Down's syndrome), or with $A P P$ mutations, have increased total tau and increased tau phosphorylation at the following key sites; Thr231, Thr181, Thr212, Thr205, Ser202 and Ser396 [12, 22-26]. These studies indicate a link between $A \beta$ production and abnormal tau phosphorylation, which correlates with the amyloid cascade hypothesis. Tau phosphorylation, however, was unchanged in neurons derived from patients with a PSEN1 mutation [24] and a recent study demonstrated that the increase in tau phosphorylation observed in neurons derived from a patient with Down's syndrome was unchanged following correction of the APP gene dosage [27]. These latter studies therefore suggest that tau may have a role in the disease that is independent of that driven by $\mathrm{A} \beta$ pathology.

Limited studies have provided the measurement of tau and tau phosphorylation in iPSC-derived neurons from SAD cell lines. Initial studies demonstrated an increase in both total tau and phosphorylated tau compared to control cell lines; although these were limited in their measurement of the Thr231 phosphorylation site only [11, 28]. More recently, the analysis of a number of other key sites in iPSCderived neurons from a SAD cell line has demonstrated an increase in tau phosphorylation at Thr205, Thr181, Thr403, Ser202, Ser400 and Ser404 compared to control [12]. Interestingly, this study also evaluated these sites in a PSENI mutant cell line and demonstrated a similar increase in this fAD cell line [12], an observation that is in contrast to the lack of tau phosphorylation in the PSEN1 fAD cell line described above [24]. In addition to the direct measurement of tau phosphorylation, the activation of glycogen synthase kinase (GSK) $3 \beta$, a tau-kinase that has been demonstrated to be responsible for abnormal tau phosphorylation in $\mathrm{AD}$, was increased in iPSC-derived neurons from SAD cell lines in a manner similar to that observed in fAD [11, 12]. However, while the demonstration of increased tau phosphorylation in $\mathrm{SAD}$ is promising for the development of SAD models, not all studies have seen these changes, with no alterations in total or phosphorylated tau being observed between SAD and control despite observed alterations in $\mathrm{A} \beta$ [29]. As discussed in further detail in "Neuronal Maturation" section, the relevance of the observed changes in tau may be limited by the maturity of the neurons and more specifically developmental regulation of tau and the expression of the immature 3-repeat isoform of tau, rather than the mature 4-repeat isoform that is implicated in the pathogenesis of $\mathrm{AD}$.

\section{Development of Other Phenotypes in SAD}

Other AD-related phenotypes such as ER stress [3] and oxidative stress $[3,29]$ have also been identified in iPSCderived neuronal models using SAD cell lines. A recent study demonstrated oxidative stress and altered mitochondrial protein expression in the absence of $A \beta$ and tau pathology in SAD [29]. This study therefore highlights the possibility of alternative or additional mechanisms of disease pathogenesis, which need to be investigated to really understand the onset and progression of SAD. Identification of such disease mechanisms may be helped by the identification of changes in AD-associated genes, including genes identified by GWAS. Alterations in gene expression in iPSCderived neurons from a SAD patient compared to control neurons identified up-regulation of AD-related pathways e.g. the response to oxidative stress, and alterations in proteasome complex units [28], indicating that genetic stratification of sAD patients may enable us to reduce the variation 
between cell lines, and promote a more consistent approach to selecting appropriate cell lines to model specific aspects of sAD. Indeed, stratification using variants of SORL1, a known genetic risk factor for $\mathrm{AD}$, has demonstrated the potential of such an approach [30] and several studies have investigated the APOE genotype of their cell lines. Genetic stratification of iPSC lines and its potential to improve SAD cell models will be discussed further in "Genetic Stratification for sAD" section.

\section{Induction of AD Using A $\beta$ Oligomers}

As the amyloid cascade hypothesis points to $A \beta$ as the trigger for the development of AD much previous work has sought to identify the toxic species of $A \beta$. Over recent years $A \beta$ oligomers (A $\beta O s)$, small aggregates of $A \beta$, have been identified as the toxic entity in initiating disease pathogenesis. Therefore, the addition of exogenous $\mathrm{A} \beta$ to initiate disease mechanisms in iPSC-derived neurons could be considered as a proof-of-principle experiment to validate this model for the study of AD. Here, we briefly discuss three studies using iPSC-derived models and the addition of A $\beta O$ S. Kondo et al., [3] demonstrated that iPSC-derived neurons from a fAD patient with an APP mutation (E693 $\triangle$ ) and one sporadic AD line had increased intracellular $A \beta O$ accumulation with associated ER and oxidative stress [3]. The effect of exogenously applied A $\beta O$ s to iPSC-derived neurons was also investigated using either secreted oligomers from 7PA2 cells [31] or a synthetic oligomer preparation [32]. These studies demonstrated that addition of secreted $\mathrm{A} \beta \mathrm{O}$ s to a control cell line induced $\mathrm{AD}$-associated changes including an increase in tau phosphorylation [31] but in contrast, addition of synthetic A $\mathrm{OO}$ s to a control cell line had no effect [32]. Addition of synthetic A $\beta O$ s did, however, result in an increase in toxicity in neurons derived from both sporadic and familial AD cell lines [32]. These studies, while highlighting the inconsistencies between different $\mathrm{SAD}$ cell lines, indicate that exogenous application of $A \beta O$ s could be a useful mechanism for induction of AD-associated pathways in the study of SAD.

\section{Building Better Models for SAD}

The development and refinement of iPSC-derived models for $\mathrm{AD}$ is ongoing and significant advances have been made. However, iPSC models and particularly iPSC-derived neurons have their limitations and using them to study SAD is particularly challenging. In this section, we highlight the major limitations of existing models and discuss how these may be overcome to generate better models for AD research, particularly for $\mathrm{sAD}$.

\section{Neuronal Maturation}

The loss of the ageing profile following reprogramming of fibroblasts to iPSCs is now well documented. Studies in iPSC-derived neurons indicate that these neurons are immature in phenotype [33] and lack markers of ageing [34]; an issue which has clear implications when using neurons derived from these cells to model $\mathrm{SAD}$, where the primary risk factor is age. Defining ageing is in itself challenging, and among many cell types, neuronal ageing has been characterised by various markers of senescence, loss of nuclear lamina (providing mechanical stability and epigenetic regulation and linked with premature ageing, for example progerin in Hutchinson-Gilford Progeria syndrome), loss of heterochromatin markers (demonstrating DNA damage) [34, 35 ] in addition to other types of oxidative stress.

Whether this 'resetting' of iPSCs and the resulting immature neurons is an issue for $\mathrm{AD}$ research is, however, a source of debate. Robust differentiation protocols to generate different types of neurons from iPSCs now exist, and with an appropriate period of maturation, electrophysiologically active neurons can be produced [23]. More importantly, these cells can produce functional neural networks, a key requirement if we are to understand the pathogenesis of $\mathrm{AD}$ [36]. The 'ageing' of neurons and the use of age-related proteins to induce ageing are discussed in the "Ageing" section but other alternative approaches in the method of reprogramming have also been proposed. Direct reprogramming, or transdifferentiation, which omits the conversion to iPSCs and directly reprograms fibroblasts to neurons [37] produced neurons with an ageing signature [4, 38]. While maintaining an ageing signature in neurons is a distinct advantage, direct reprogramming approaches are less well characterised and less efficient. In addition, differentiation of iPSCs to cortical neurons has been shown to mimic development in vivo, including the spontaneous generation of glial cells such as astrocytes, and may therefore have some advantages in modelling $\mathrm{AD}$ progression [39]. Ghaffari et al. provides a detailed review and comparison of iPSC differentiation and direct reprogramming to generate models for neurological diseases including AD [40].

One of the key limitations of iPSC-derived 'immature' neurons to study $\mathrm{AD}$, and other tauopathies, is the lack of a mature tau isoform profile in these neurons. Tau is alternatively spliced to produce six isoforms which differ by the expression of the number of $\mathrm{N}$-terminal repeats $(0 \mathrm{~N}, 1 \mathrm{~N}$ and $2 \mathrm{~N}$ ) and the number of microtubule binding regions ( $3 R$ and $4 R$ ). This splicing is developmentally regulated, with foetal expression of the $0 \mathrm{~N} 3 \mathrm{R}$ tau and expression of the longer tau isoforms considered a mature (adult) tau profile. Disruptions in tau splicing and an increase in 4-repeat tau isoforms are seen in disease with 4-repeat tau being more prone to aggregation. iPSC-derived neurons predominantly 
express 3-repeat tau and, while expression of 4-repeat tau has been observed, extensive culture (150-365 days) was required [41]. The tau profile observed in neurons generated by transdifferentiation has not, to our knowledge, been reported and while alterations in tau phosphorylation have been observed $[4,38]$, such modifications of tau have also been demonstrated in iPSC-derived neurons [11, 42]. Whether the ageing profile of neurons derived either from iPSCs or via transdifferentiation protocols is a key limitation in the study of SAD remains to be determined. It is possible that the lack of mature tau isoforms may prevent the activation of key toxicity pathways involved in $\mathrm{AD}$ and that the development of more mature neurons is required before accurate modelling of SAD pathogenesis can be achieved.

\section{The Role of Glial Cells in Modelling sAD}

Neurons do not exist in isolation in the brain and there is compelling evidence that glial cells, particularly microglia and astrocytes, are implicated in the onset and progression of AD. Until recently, the ratio of neurons to glial cells in the brain was suggested to be around 10:1 but this ratio may be more like 1:1 and vary between brain regions [43]. While it would be helpful if a consensus could be reached, it is undeniable that glial cells play a role in the onset and progression of $\mathrm{AD}$. Whether the role of glial cells in SAD is distinct from that in $\mathrm{ADD}$ has yet to be determined but evidence from the identification of AD risk genes enriched in glial cell types, e.g. APOE4 in astrocytes and microglia and TREM2 in microglia, suggests that this may be a key area for investigation. In this section, we will discuss the role of glial cells, focussing on their role in $\mathrm{AD}$, and whether co-culture and/or three-dimensional (3D) culture models may be more physiologically relevant to aid in our understanding of the mechanisms involved in the onset and progression of SAD.

\section{Astrocytes}

Astrocytes maintain a range of functions but are crucially involved in the clearance of metabolites and toxins, including the clearance of $A \beta$. Astrocytes, which exist in a quiescent state, can become reactive in $\mathrm{AD}$ in response to increasing $\mathrm{A} \beta$. This results in molecular and morphological changes causing alterations in their function including the altered uptake and metabolism of $\mathrm{A} \beta$, changes in calcium homeostasis leading to calcium overload and a reduction in the clearance of glutamate and other neurotransmitters resulting in synaptotoxicity [44]. While the AD field has to date, been somewhat neuron-focussed, the implications of astrocyte dysfunction in $\mathrm{AD}$ suggest that addition of astrocytes to neuronal cultures would be of real benefit in our attempts to model sAD. Critically, as discussed above, the mechanism of increased $A \beta$ levels in $\mathrm{SAD}$ is likely due to decreased
$\mathrm{A} \beta$ clearance and metabolism, rather than increased production. As astrocytes express and secrete the majority of known A $\beta$-degrading enzymes (including NEP and IDE) and are responsible for a large part of extracellular $A \beta$ uptake and breakdown [45], astrocyte impairment in AD may significantly contribute to the development and progression of sAD pathology [46]. Studies on astrocytes have also demonstrated a role in the production of $A \beta$, potentially through an increase in BACE1 activity in reactive astrocytes indicating that in addition to decreased clearance, astrocytes could also play a role in $\mathrm{SAD}$ by increasing $\mathrm{A} \beta$ production [47]; although this goes against the hypothesis that $\mathrm{SAD}$ is due to decreased clearance of $A \beta$. Detection of $A \beta$ from single astrocytes demonstrated a sub-population of cells with high levels of secreted $A \beta$ [48], suggesting that sub-populations of astrocytes may play conflicting roles in AD. In support of a role for astrocytes in $\mathrm{SAD}$ is their production of the ApoE protein, the $\mathrm{E} 4$ isoform of which has a clear genetic link to $\mathrm{SAD}$, which will be discussed in further detail in "Building Better Models for sAD" section.

Several differentiation protocols to produce astrocytes from iPSCs have been published [49-53], including direct conversion to iAstrocytes [54]. While these protocols generate astrocytes with the expected morphology and appropriate expression of astrocytic markers, questions remain around their maturity [51] and their relevance for accurately modelling the changes that occur in SAD. Astrocytes have been generated from iPSCs from patients with fAD with PSEN1 mutations; PSEN1 $\triangle \mathrm{E} 9$ [47], and PSEN1 M146L [55]. There was no difference in the astrocytic differentiation between the control and PSEN1 $\triangle \mathrm{E} 9$ cell lines, but a role for astrocytes in $\mathrm{AD}$ pathology in the $\mathrm{AD}$ lines was observed, including increased $\mathrm{A} \beta 42$ and calcium dysregulation, as well as changes in metabolism that resulted in increased oxidative stress [47]. Differences in astrocyte, but not neuron, morphology, during differentiation were observed between the control and PSEN1 M146L cell lines and this study also demonstrated alterations in morphology of astrocytes derived from iPSCs from patients with the APOE4 allele, a genetically defined SAD model [55]. This has recently been further supported by altered gene transcription in iPSCderived astrocytes between isogenic APOE3/E3 to E4/E4 cell lines [56]. Astrocyte dysfunction was also observed in astrocytes generated from an APOE4 cell line compared to a control in their role in $A \beta$ degradation and clearance [57] with impaired $A \beta$ uptake [56].

\section{Microglia}

Microglia play a distinct role as the innate immune cells of the CNS and in AD have been shown to accumulate as a result of increased $A \beta$ levels, to promote $A \beta$ clearance and prevent the formation of amyloid plaques. However, 
during disease progression, down-regulation of key genes as a result of proinflammatory cytokine production results in a reduction in $\mathrm{A} \beta$ clearance, promoting $\mathrm{A} \beta$ accumulation and the formation of amyloid plaques [58, 59]. Genetic risk factors for $\mathrm{SAD}$ have identified some key genes enriched in microglia; TREM2, CR1, CD33 and MS4A have been identified through GWAS and expression of APOE4 has also been shown to cause phenotypic changes in microglia including impaired $\mathrm{A} \beta$ uptake and inflammatory gene activation [56, 60].

Differentiation protocols for derivation of microglia from iPSCs have been difficult to develop due to the distinct developmental origin of microglia, but recently protocols have emerged to produce cells with transcriptomic profiles highly similar to human adult microglia [61-64]. These iPSC-derived microglia-like cells have been used successfully with cortical neurons in 2D [64] and in 3D organoid co-cultures $[62,65]$, where the microglia-like cells infiltrated the neuronal organoid [65], responded to the neuronal environment [62] and mediated an inflammatory response [64]. In addition, these iPSC-derived microglia-like cells were able to internalise both fibrillar $\mathrm{A} \beta$ and brain-derived tau oligomers [62].

\section{Oligodendrocytes}

Oligodendrocytes generate the myelin sheaths around axons; however the idea that they are just the myelinating cells of the CNS has been recently revised with the suggestion that a subset of proliferative, immature oligodendrocytes may play a role in CNS functionality including in neural repair [66]. A $\beta$ oligomers caused a decrease in myelin proteins [67] and were toxic to oligodendrocytes [68]. There is also evidence that changes in the morphology of oligodendrocytes is altered in $\mathrm{AD}$ [69] suggesting that oligodendrocytes may too have a role to play in the onset and progression of $\mathrm{AD}$. Oligodendrocytes have been successfully generated from iPSCs [70-72] but the evaluation of the role they may play in $\mathrm{AD}$, and their relevance in $\mathrm{SAD}$ models has, as yet, not been reported.

\section{Cells of the Neurovascular Unit}

The role of the NVU (reviewed by Ladecola [73]) in neurodegenerative disease, including in $\mathrm{AD}$, has recently attracted significant attention, and the role of neurovascular alterations in disease has become more widely appreciated. In AD this relatively new direction of research links together clinical observations; the existence of ischaemic lesions with $\mathrm{AD}$ pathology, links between vascular dementia and $\mathrm{AD}$, and the role of neurovascular dysfunction in patients with cerebral amyloid angiopathy (CAA), which have begun to demonstrate the importance of the NVU [74]. Endothelial cells [75] and mural cells (vascular smooth muscle cells and pericytes) [76] can be generated from iPSCs. With increasing interest in the role of the NVU, the generation of in vitro cell models to allow effective investigation into the role of the NVU in $\mathrm{AD}$ are being developed. By definition of the NVU, these models use co-culture of different cell types, with successful quadruple-culture of endothelial cells with neural stem cells, astrocytes and pericytes reported [77]. Modelling of the NVU has also generated interest from a biomaterials perspective, and three-dimensional (3D) models of the NVU are in development [78].

\section{Neuron and Glial Co-culture Models}

While development of robust protocols to generate neurons and glial cell types continues, recent approaches have started to explore the co-culture of different cell types to better understand the interplay between them. Culture of human neurons with rodent astrocytes to aid growth, support and maturation of the neurons has been utilised successfully [11]. Modification of the extracellular matrix by neurons and astrocytes regulated the formation, maintenance and function of the synapse (reviewed by Dzyubenko et al. [79]) highlighting why maturation of iPSC-neurons may be quicker in the presence of astrocytes. However, while this is of benefit in neuronal model development, the incorporation of glia into neuronal cultures derived from iPSCs from sAD patients may reveal distinct phenotypes and indicate novel research avenues not identified by culturing neurons, or indeed glial cells, in isolation. As discussed above, all of the glial cell types have been shown to potentially play a role in the disease, indeed reactive gliosis, the activation and proliferation of glial cells, as a response to neuronal damage has been seen in all neurodegenerative diseases [80].

Due to their common neuroepithelial origin, spontaneous differentiation of astrocytes in neuronal cultures has been observed with extended culture at around day 70 post neural induction $[23,39]$. Therefore neurons generated using these methods may exist in co-culture with astrocytes, dependent on the length of culture. More directed co-culture methods can be applied with the most simplistic models involving the co-seeding of two, or more, cell types. Co-seeding of iPSCderived neurons and astrocytes has been employed demonstrating improved functional maturation of neurons with astrocyte co-culture in both 2D [81] and in 3D organoids [49]. A co-seeding approach allows cells to be seeded in more relevant ratios, although as discussed previously, glial cell number in the brain is regionally specific and is still not clearly defined. More complex systems are available, including culture on transwell inserts and in microfluidic chambers which allow for more subtle investigation of the interaction of different cell types, particularly with regard to the secretion of vesicles and/or soluble factors and their effect on a 
secondary cell population. Development of co-culture in 3D adds an additional layer of complexity to potential co-culture models. Current approaches for 3D modelling will be discussed in the next section, but as described above, successful co-culture of iPSC-derived microglia $[62,65]$ and astrocytes [49] with 3D cortical organoids has been used. The development of cell models which explore either the direct physical interactions or the biochemical interactions between different cell types will no doubt further our understanding, but while generation of these co-culture models may be difficult, characterisation of the role of each cell type in co-culture may prove to be just as challenging.

\section{Three-Dimensional Neuronal Culture}

While there are a number of different neuronal differentiation protocols, the majority involve the 'two-dimensional' culture of cells on coated wells of cell culture dishes. It has been proposed that a 3D culture model would better recapitulate the in vivo environment promoting the maturation of neurons, suggesting that $3 \mathrm{D}$ culture could potentially resolve one of the greatest challenges in the use of iPSC-derived neurons for studying age-related diseases. In addition, the characterisation of $\mathrm{AD}$ relies on the identification of $\mathrm{A} \beta$ plaques and NFTs, while neurons are maintained in 2D culture with regular replacement of cell culture media, deposition of $A \beta$ and the formation of NFTs cannot be observed under culture conditions. The advantage of $3 \mathrm{D}$ culture may therefore not only be to help to accelerate neuron (and glia) maturity but also allow the accumulation of these pathogenic proteins in vitro.

3D culture, in vitro, can be broadly categorised in to two groups: 3D culture using cells in a scaffold-based gel structure and self-organising scaffold-free structures such as organoids. Neuronal organoid cultures derived from iPSCs through embryoid body formation have gained momentum in recent years with a number of protocols being developed [39, 82-84]. The benefits and limitations of these organoids have been recently well reviewed [8] and studies are now emerging using these organoids to model AD using fAD [26] and sAD cell lines [85, 86]. Of note, the analysis of the $3 \mathrm{D}$ organoids from sAD patient lines included proteomic profiling which was directly compared with brain tissue proteomics identifying key proteins in axonal injury and oxidative stress in the AD brains and 3D neuronal cultures compared to controls [86]. Interestingly in terms of potential treatment development, it was also demonstrated that the $5 \mathrm{AD}$ cell lines used displayed a differential response to BACE1 and $\gamma$-secretase inhibitors.

Scaffold-based 3D neuronal cultures for the study of $\mathrm{AD}$ currently appear to be more limited, but commercially available, scaffold-based gels such as matrigel [87-89] and puramatrix [90] have been used successfully for
iPSC-derived neuronal culture. Other hydrogel scaffolds have also been developed, including collagen [91], silkbased scaffolds [92], and synthetic hydrogels [53, 93]. Such hydrogels are easily tuneable and can be supplemented with additional extracellular matrix proteins, providing the potential for investigation of the influence of specific proteins in $\mathrm{AD}$, such as heparan sulphate proteoglycans which have been shown to promote amyloid pathology. Modulating the gel matrix to promote amyloid pathology may be a useful tool in the study of $\mathrm{SAD}$ as, to date $\mathrm{A} \beta$ deposition has not been shown in genetically unaltered iPSC-derived neurons. $\mathrm{A} \beta$ deposition was seen in $3 \mathrm{D}$ culture of human neural progenitor cells in matrigel, however, these cells were overexpressing both $A P P$ and $P S E N 1$ mutations [87, 88]. Interestingly in these cells culture in 3D was also seen to increase 4-repeat, adult tau compared to 2D culture [87]. Whether culturing of iPSC-derived neurons from SAD patients will enable the development of $\mathrm{AD}$ pathology in vitro, remains to be seen. It is possible that both co-culture and 3D culture need to be combined to better recreate the neuronal environment to allow both the physical and biochemical connections needed. More complex structures within hydrogel matrices may be a way to develop such models and the development of technologies such as 3D bioprinting may enable such models to be generated [94].

An alternative to in vitro 3D models has recently been suggested with the proposal of a human-mouse chimeric model to provide a 'natural 3D culture environment' and the characterisation of this model for $\mathrm{AD}$ [95]. In this work, neural progenitor cells were grafted into the brains of a transgenic $\mathrm{AD}$ mouse model, thus exposing them to $\mathrm{A} \beta$ deposits and the resultant neuroinflammatory responses produced by the AD mouse. The effect of this culture environment resulted in neuronal loss that was seen only with grafted human neurons and not with grafted mouse neurons. One key finding from this work was the presence of a significant amount of 4-repeat tau at 6-8 months post transplantation indicating that this 'natural' 3D environment can evoke accelerated neuronal maturation and subsequent abnormal tau phosphorylation, albeit in the absence of tau tangle pathology [95]. This work provides an alternative strategy for investigating $\mathrm{AD}$ using human neurons, but how widely this model will be utilised, given its technical complexity remains to be seen.

\section{Genetic Stratification for SAD}

Identification of a large number of genetic risk factors associated with SAD gives a strong indication of the complexity of the disease. This suggests that initiation of SAD may not always be driven by identical mechanisms, which may explain the inconsistencies observed between cell lines from different SAD patients [11]. We propose that genetic 
stratification of SAD lines and their association with particular disease phenotypes may progress our understanding of sAD onset, and enable more consistent data to be obtained.

The variability in iPSCs from different donors is known to be due to the genetic variation between individuals, rather than differences in the production of iPSCs, particularly as a result of the cell type or origin due to residual epigenetic signatures [96-98]. Large scale studies from the Next Gen consortium, have demonstrated in over $300 \mathrm{iPSC}$ lines from over 100 individuals that around $50 \%$ of the variation is due to genetic differences [98] which is in agreement with an independent study utilising over 700 cell lines from over 300 individuals [99]. This overwhelming evidence of the genetic variation identifies the importance of genetic stratification for the study of disease and highlights the limitations of existing studies using a small number of lines from a select number of individuals without genetically matched controls. While this implies that there is still much work to be done to accurately model complex diseases such as SAD, the use of large study cohorts to overcome these limitations and identify key genes [99, 100], including the validation of GWAS variants [101] and functional genetic variation [102] is extremely promising for the future.

A significant factor in the genetic stratification of cell lines will be the generation of isogenic control lines. Variability exists in control cell lines as well as in SAD cell lines, and it is possible that control cell lines may contain a genetic risk factor for SAD. Such variability creates an amount of 'noise' in the system that renders the analysis of data almost impossible with very little likelihood of ever achieving statistical significance. The creation of isogenic control lines will enable a direct comparison to be made and will limit the number of cell lines needed for analysis of any particular risk factor. The discovery of CRIPSR/Cas9 gene editing has made the generation of isogenic cell lines possible. CRISPR/ Cas9 gene editing has been used to create isogenic control lines from fAD models with mutations in APP [103], PSEN1 [104, 105], and PSEN2 [103]. In addition, fAD mutations in APP and PSENI have also been introduced into a control cell line [106]. However, the use of this technology with iPSCs is not straightforward [106-108] and the effort to generate these isogenic controls should not be underestimated.

Identification of proteome changes in iPSC-derived neurons from SAD cell lines has been demonstrated, with changes in proteins encoded by genes identified by GWAS, including proteins involved in $\mathrm{A} \beta$ production and its clearance [28]. The study highlights the use of proteomics and the analysis of protein interaction networks to observe early molecular changes in SAD that may contribute to disease progression, indicating that such methods may be valuable in the identification of a patient-specific cause of disease [28]. While such studies are encouraging and indicate that genetic stratification for SAD is worth pursuing, the validation of the identified genetic risk factors is still needed to enable the field to focus on those known to impact on disease onset and progression. Highlighted below are some of the key genes identified as risk factors for the development of SAD, discussed in terms of the two mechanisms identified in the "Investigating sAD Using iPSC-Derived Neurons" section: $A \beta$ production or $A \beta$ clearance. We have not aimed to provide an exhaustive list of risk genes associated with SAD, but discuss validated genes and existing studies in iPSCderived models.

\section{Genetic Risk Factors Altering A $\beta$ Production}

Increased $A \beta$ as a result of alterations in APP processing have been clearly demonstrated, through studies on the fAD-associated mutations in APP and PSEN1, to lead to $A D$ pathogenesis. Several of the genetic risk variants associated with $\mathrm{SAD}$ have also been shown to cause an increase in the production of A $\beta$. Mutations in ADAM10, the enzyme primarily responsible for the $\alpha$-secretase cleavage of APP, decreased $\alpha$-secretase cleavage of APP resulting in a concomitant increase in $\beta$-secretase cleavage causing increased $\mathrm{A} \beta$ production [109]. A number of genes have also been implicated in increased $A \beta$ production via alterations in the localisation and trafficking of both APP and the secretases. SORL1 variants, identified as a risk gene for SAD by GWAS, altered APP trafficking causing increased $A \beta$ [110], while genetic variants of PICALM, BINI and CD2AP, also identified as risk genes for SAD by GWAS, demonstrated altered trafficking of APP due to altered clathrin-mediated endocytosis [111]. PICALM also affected the trafficking of $\gamma$-secretase resulting in alterations in the $A \beta 42: 40$ ratio [112]. $A \beta$ production can also increase as a result of increased APP expression, such as is seen with APP duplication in Downs' syndrome. Both APOE [113] and $C L U$ [114], genes identified as risk factors for $\mathrm{SAD}$, altered APP expression. APP transcription has been shown to be stimulated by $A P O E$ in an allele dependent manner [113], while decreased levels of clusterin, which like APOE regulates cholesterol metabolism, have been shown to increase APP expression [114]. Variants of $C L U$ that decrease its functional capacity would be expected to increase APP expression, thereby increasing $\mathrm{A} \beta$ production.

\section{Genetic Risk Factors Altering A $\beta$ Clearance}

Several identified risk genes for sAD mediate their effect by decreasing $\mathrm{A} \beta$ clearance. $A P O E$ and $C L U$, which both play a role in cholesterol uptake, are involved in the uptake and clearance of $A \beta$ [115]. Cholesterol depletion resulted in a decrease in $A \beta$ uptake and clearance. APOE also mediates clearance of $A \beta$ through the BBB which is mediated by the $A \beta$ chaperone proteins, receptor for advanced glycation 
end products (RAGE) and low-density lipoprotein receptor related protein-1 (LRP1). Mutations in LRP1 have been identified, and PICALM, identified as a risk factor for $\mathrm{SAD}$, has a role in mediating LRP1 function, suggesting an additional role for PICALM [112]. An iPSC-derived endothelial cell model demonstrated that a protective mutation in PICALM resulted in increased clearance of $\mathrm{A} \beta$ [112]. A $\beta$ clearance can also occur through phagocytosis and mutations in $A B C A 7$, a lipid transporter that plays a role in the phagocytic removal of $A \beta$ has also been identified as risk gene for SAD [116]. Decreased proteolytic A $\beta$ degradation has also been implicated, as NEP expression is decreased with age and associated with the accumulation of $A \beta$ plaques [24]. NEP polymorphisms increased the risk of sAD [117, 118] and identified polymorphisms in $I D E$ also increased the risk of developing SAD [119].

\section{Using iPSC-Derived Models with Genetic Risk for SAD}

$A P O E$ is arguably the most well-studied gene in SAD with several possible pathological functions including in mitochondrial dysfunction, decreased lipid, cholesterol and glucose metabolism, increased tau phosphorylation, increased neuroinflammation and, as indicated above, increased $A \beta$ via increased APP expression and decreased clearance [18, 19, 120-122]. In iPSC-derived cholinergic neurons from sAD patients with an APOE4 allele, several phenotypic changes were observed. The APOE3/E4 genotype of the sAD patients resulted in neurons with more susceptibility to neurotoxic stimuli, and increased calcium levels resulting in neuronal excitotoxicity compared to control neurons [123]. APOE4 expression in iPSC-derived neurons has since been shown to result in increased $A \beta$ production and increased tau phosphorylation causing GABAergic neuron degeneration [124]. Linked to APOE, the expression of SORL1, a neuronal APOE receptor, was decreased in iPSC-derived neurons carrying the APOE4 allele, resulting in increased $\mathrm{A} \beta$ [125]. Protective variants in SORL1, have also been shown, in iPSC-derived neurons from SAD patients and controls (including cell lines used in Israel et al., Gore et al., and Woodruff et al., to decrease $A \beta$ levels $[11,25,30,126])$.

Despite being the largest genetic risk factor for $\mathrm{SAD}$, the presence of APOE4 does not guarantee $\mathrm{AD}$ onset, indicating that interaction with additional genetic or environmental risk factors may be involved. Indeed there are many identified risk genes that associate with each other and with specific environmental risk factors. However, the studies in iPSCderived models, to date, indicate that specific phenotypes exist as a result of genetic variants and highlight that genetic stratification of sAD cell lines may be beneficial both in understanding the disease and for targeting therapeutics. While this is certainly promising, significant progress still needs to be made to validate identified genetic risk factors, stratify iPSC lines, identify the key cell type through which each risk factor may mediates its effects and understand the extent to which susceptibility genes interact with each other and with environmental factors.

\section{Environmental and Genetic Risk Factors}

The lack of a clear genetic cause suggests that the development of sAD is also heavily influenced by environmental risk factors. Here, we define environmental risk factors to mean a non-genetic, external modifier. At present there are several factors that have been identified as increasing the risk of developing SAD. This section looks briefly at what these environmental risk factors are, how they contribute to AD pathology, and whether they have, or can be, modelled using iPSC-derived cell lines to progress our understanding of sAD. We also identify where key risk genes have been identified linking to these specific environmental factors to highlight where a combined approach of genetic stratification and modulation of an environmental risk factor may help us progress our models of SAD.

\section{Ageing}

Ageing is by far the largest risk factor for the development of $\mathrm{AD}$, but the effects are complex, difficult to define and are still not completely understood. Age-related changes result in increased $A \beta$ deposition; for example, failure of perivascular drainage results in deposition of insoluble $A \beta$ in arterial walls that prevents the removal of soluble $A \beta$, possibly due to the ageing and stiffening of arteries and the build-up of fibrillar $A \beta$ [127]. As discussed previously, the epigenetic changes that occur with ageing are lost in the reprogramming of iPSCs; therefore, aside from using transdifferentiation protocols to maintain such changes, the use of iPSC-derived cell models will require stimulation of ageing through identified age-related proteins (e.g. progerin or inhibition of klotho) or by cell stress to induce premature ageing. Progerin promotes premature ageing and iPSC-derived smooth muscle cells from a patient with Hutchinson-Gilford Progeria syndrome have been shown to have markers of premature ageing following differentiation [128]. Klotho, an anti-ageing protein, protects neurons from oxidative stress [129] and its expression reverses ageing; klotho deficiency may therefore promote ageing. Indeed, when klotho expression was deficient, an accelerated ageing phenotype was observed due to activation of wnt signalling resulting in the depletion and senescence of stem cells [130]. Klotho has also been shown, in mouse models, to mediate autophagy which may have additional implications on $A \beta$ deposition. While modulation of progerin and klotho may provide a way 
to age iPSC-derived models for the study of sAD, cell stress enables the stimulation of ageing without requiring genetic modification.

\section{Oxidative Stress}

Oxidative stress, or the generation of ROS, results in a multitude of damaging cellular effects. While the overall effect on cellular ageing is still to be investigated, mitochondria are considered to be the largest contributors of ROS [131] and both oxidative stress and mitochondrial dysfunction (discussed below) are strongly implicated AD as well as other neurodegenerative diseases [132]. Oxidative stress plays a role in $\mathrm{A} \beta$ degradation and clearance (reviewed by Cheignon et al. [133]). As previously described, iPSC-derived astrocytes from $\mathrm{AAD}$ patients showed increased levels of oxidative stress [47] and iPSC-derived neurons from both fAD [47] and SAD [3] patients were more reactive to $\mathrm{H}_{2} \mathrm{O}_{2}$ treatment. There are several genetic risk genes that may affect the neuronal response to oxidative stress including BMII, expression of which decreased in the AD brain, and more recently in iPCS-derived cortical neurons from SAD patients [134]. Given the links of oxidative stress to other genetic and other environmental factors (as described below), induction of oxidative stress may offer a solution to induce $\mathrm{AD}$ in an iPSC-derived SAD model.

\section{Hypoxia}

Hypoxia has been proposed as a mechanism contributing to AD pathology and conditions causing hypoxia, such as stroke, ischaemic injury, cardiac arrest and neurovascular disease, are identified risk factors for the development of $\mathrm{AD}[135,136]$. Hypoxia caused increased $\mathrm{A} \beta$ deposition in AD mouse models [137-139] and this effect was shown, both in cells and in AD mouse models, to be regulated by an increase in $\gamma$-secretase activity resulting from the direct interaction of $\gamma$-secretase with hypoxic-inducible factor $1-\alpha$ (HIF-1 $\alpha$ ) [140], or via the demethylation of the gene encoding $\gamma$-secretase [141]. Activation of HIF- $1 \alpha$ by mitochondrial ROS production upregulated BACE1 expression, increased BACE1 activity and thereby contributed to increased $A \beta$ deposition in hypoxia [142]. Clearance of $A \beta$ may also be impaired as the $\mathrm{A} \beta$-degrading enzymes endothelial converting enzyme 1 (ECE-1) and NEP were downregulated during hypoxia, while conversely IDE was upregulated by hypoxia [143-146]. Hypoxia also resulted in increased tau phosphorylation at several sites in the hippocampus $[90,147]$ but whether this occurs as a direct effect of increased $A \beta$ levels has not been confirmed.
The application of hypoxic conditions in iPSC-derived sAD models has not been widely explored. Hypoxia has been widely utilised for the generation and maintenance of pluripotency, and also for the directed differentiation of iPSCs to a neural fate [148-150]. Using hypoxic conditions during the differentiation stage of iPSC-derived cells may affect maturation of different cell types which could be of benefit when deriving iPSC neurons or astrocytes, where the maturity of these cells is of concern. Post differentiation, the use of hypoxia to simulate an environmental risk factor with well characterised AD pathology may be an excellent method for cell modelling due to the relative ease with which the severity of oxygen deprivation can be modified to mimic either acute injury (i.e. stroke) or chronic conditions (i.e. ageing) by adjusting both oxygen conditions and length of exposure.

\section{Inflammation}

Neuroinflammation clearly plays a role in AD and other neurodegenerative diseases, although whether it is harmful or protective is still a source of debate. It is possible, however, that it plays both roles and that the effect of inflammation may be cell dependent. Microglia and astrocytes both mediate an immune response in the brain. Microglia can be activated to become anti-inflammatory, where debris is cleared through phagocytosis, or pro-inflammatory, with the release of ROS and cytokines [151]. Astrocytes which become reactive during cell stress are traditionally considered to have a neuroprotective role. However, in conditions mimicking neuroinflammation, astrocytes lose many of their normal functions and become destructive [152]. Neuroinflammation was originally considered a secondary effect of $\mathrm{AD}$ due to the build-up of $\mathrm{A} \beta$ plaques and NFTs, but increasing evidence suggests that inflammation contributes to the early development of disease [153]. Pertinent to a key role in SAD, several risk genes associated with the inflammatory response have been identified, including TREM2 which has been investigated in iPSC-derived neurons, albeit in a model of frontotemporal dementia [65]. Induction of a pro-inflammatory environment to mimic changes occurring in $\mathrm{AD}$ can be easily achieved using cytokines, and the use of such models have been well described, although not, to date, in iPSC-derived cells. iPSC-derived neurons, however, have been treated with $\mathrm{H}_{2} \mathrm{O}_{2}$ and $\mathrm{NO}$ to model oxidative stress and inflammation, where viability was dramatically reduced. This was further exacerbated in both SAD and fAD lines. Notably, apigenin which may inhibit NF- $\mathrm{KB}$ activity, protected against inflammation induced cell death [154]. For future models of inflammatory responses in iPSCs the influence of both astrocytes and microglia need to also be assessed, 
especially as these cells play such an important role in $\mathrm{A} \beta$ degradation and clearance.

\section{Metabolic Changes}

Changes in energy metabolism are a key characteristic observed in ageing and in the early stages of AD. Longitudinal studies have also demonstrated links between $\mathrm{AD}$ and metabolic disease, including Type 2 diabetes mellitus (T2DM) and metabolic syndrome (MetS) [107], and in particular have demonstrated that obesity is a clear risk factor for AD. Obesity causes a low-grade inflammatory response, due to activation of PPR, IKK $\beta$ and NF- $\mathrm{KB}$, which results in metabolic dysfunction (reviewed by Lumeng and Saltiel [155]). In addition, obesity also results in changes in glucose availability and insulin signalling [156], which are also altered in both T2DM and MetS. Changes in both glucose and insulin can cause alterations in $A \beta$ levels which may lead to the development of sAD. The A $\beta$-degrading enzyme IDE preferentially binds insulin over $A \beta$ and when insulin levels are high, as happens in the early stages of T2DM and MetS, the increased insulin results in competitive inhibition of A $\beta$ binding and its degradation by IDE [157, 158]. Conversely, it has been demonstrated in a mouse model which does not produce insulin, that when insulin levels were low, such as occurs in later stage diabetes, IDE expression was significantly decreased [159]. IDE can also be influenced by alterations in glucose levels, first as changes in glucose levels result in associated changes in insulin levels, and second, because high glucose levels can directly inhibit IDE activity through s-nitrosylation [157]. The dysregulation of insulin and glucose in T2DM and MetS demonstrates how a potential environmental risk factor may cause $\mathrm{SAD}$; whether such changes can be utilised to drive the onset of $\mathrm{SAD}$ in iPSC-derived models, remains to be seen.

\section{Mitochondrial Dysfunction}

Part of the metabolic changes associated with an increased risk of sAD are changes in oxygen consumption which link to mitochondrial function. Mitochondria play a vital role in cellular energy production and are also involved in apoptosis and calcium homeostasis. Mitochondrial dysfunction resulting from alterations in mitochondrial membrane proteins, have been linked with AD due to alterations in APP expression and APP processing which lead to increased A $\beta$ accumulation. Furthermore, mitochondrial dysfunction leads to increased oxidative stress and inflammation and has been shown to increase tau phosphorylation, although whether these effects directly cause SAD or are an associated change as a result of disease onset has not been fully elucidated (reviewed by Swerdlow et al. [160]).
Mitochondrial dysfunction has been explored in several different iPSC-derived neuronal models of neurodegeneration. In iPSC-derived neurons from SAD patients, mitochondrial dysfunction was observed as a result of increased formation of oxidative phosphorylation chain complexes resulting in increased ROS production [29]. In addition, it has been hypothesised that the increased sensitivity to ROS that has been observed in iPSC-derived neurons from SAD patients is due to mitochondrial stress [12]. Mitochondrial dysfunction, leading to oxidative stress, was observed in iPSC-derived neurons from patients with familial mutations in PINK1, PARK2 and TAU that cause either Parkinson's disease or frontotemporal dementia [161-163]. This interestingly links to studies from iPSC-derived neurons from a fAD patient with a PSEN1 mutation where decreased mitophagy and autophagy have been reported due to changes in PINK1 and PARK2 [164]. These studies indicate that mitochondrial dysfunction could initiate the onset of SAD by triggering a number of key pathways and responses in iPSC-derived cell models.

\section{Future Directions and Outstanding Questions}

Research using defined iPSC-derived neuronal models from fAD patients demonstrates the success of this approach to investigate $\mathrm{AD}$. The measurable changes that can be observed in $A \beta$, tau and related proteins in neurons derived from fAD cell lines have enabled further understanding of the onset and development of pathology in human neurons which is of great benefit to the field. In contrast, however, despite encouraging elements in the analysis of AD pathology in iPSC-derived neurons from sAD patients, the inconsistency in the production of an 'AD phenotype' suggests that further refinement of these models is required to allow us to fully investigate the causes and mechanisms of the disease and its progression. We have summarised the factors described in this review that need to be considered in modelling sAD in Fig. 1.

The future of using iPSC-derived models in the study of SAD requires several key areas to be addressed, summarised below as four key questions:-

1. Can we recapitulate disease progression by $3 \mathrm{D}$ culture of neurons and glial cells?

2. Will genetic stratification of iPSCs by SAD risk genes develop more consistent models?

3. Is A $\beta$ clearance impaired in iPSC-derived SAD models?

4. Does the application of environmental risk factors promote the onset of a SAD phenotype in iPSC-derived neurons? 


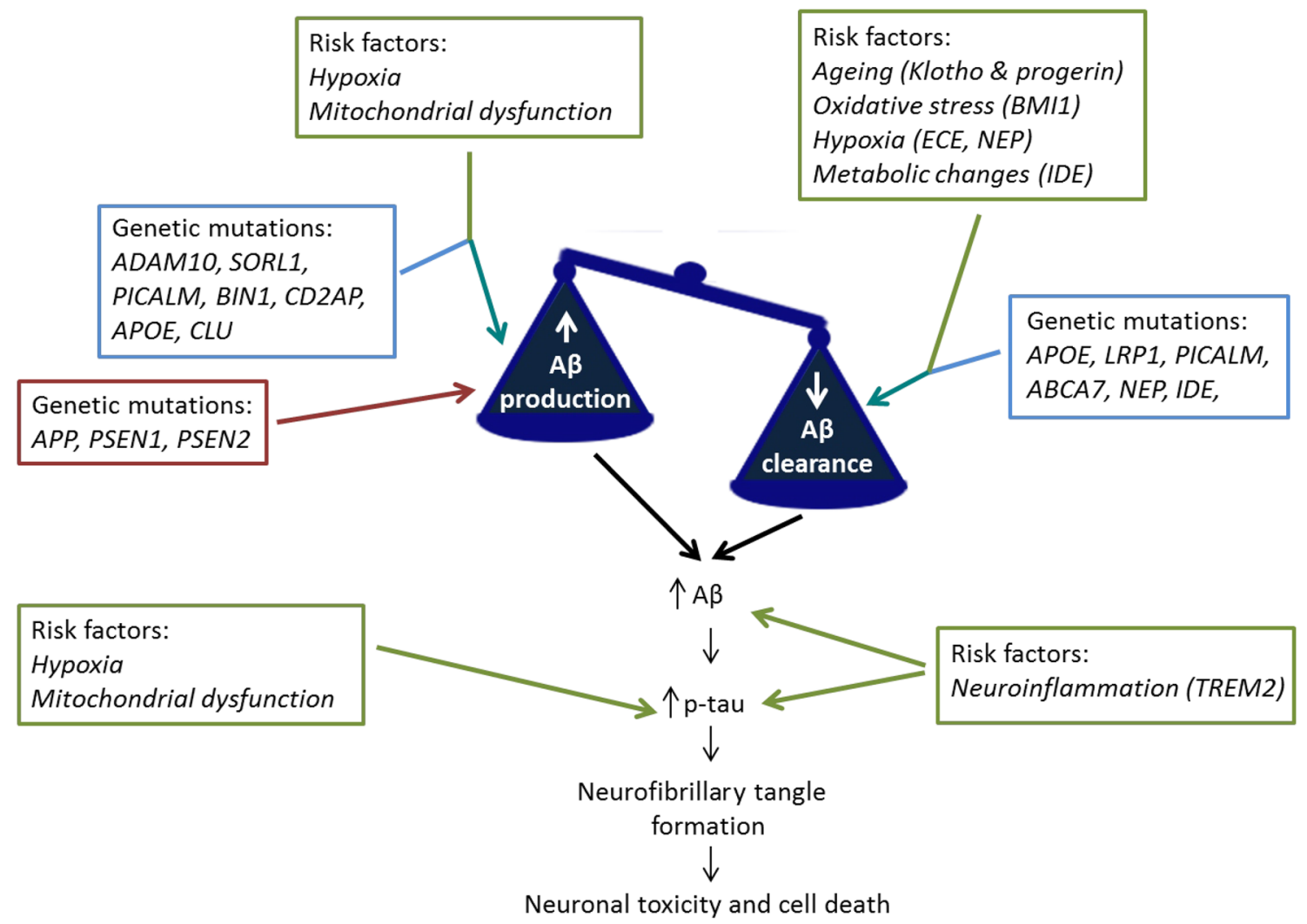

Fig. 1 Modelling sporadic Alzheimer's disease. fAD $\square$ is caused by genetic mutations that drive increased $A \beta$ production. In contrast $\mathrm{SAD}$ is caused by multiple linked factors that disrupt the balance between $\mathrm{A} \beta$ production and $\mathrm{A} \beta$ clearance. These factors include genetic mutations $\square$ and environmental and genetic risk factors $\square$.

iPSC-derived models are advancing, including the development of co-culture to include glial cells and 3D culture with the aim to both mature neurons more rapidly and to create a more physiologically relevant model to study the disease. While the use of fAD cell lines in more complex culture models will hopefully start to delineate disease mechanisms, the generation of iPSC lines from SAD patients may still not give consistent results. This lack of consistency has implications not only in developing our understanding of the onset and progression of sAD, but also in the development of treatments, particularly with the move towards personalised medicine. Therefore, we propose that genetic stratification of cell lines may address some of the inconsistencies observed between different SAD iPSC models and such stratification may identify key pathways for investigation in a given cell line. This will, however, require not only the stratification of existing lines, but the development of isogenic controls. In this review, we have discussed genetic stratification in terms of $A \beta$ production vs $A \beta$ clearance to highlight the potential role of $A \beta$ clearance in the onset and progression of $\mathrm{SAD}$. While not neglecting alterations resulting in increased $A \beta$ production, we consider that $A \beta$
We propose that more successful models of sAD using iPSC-derived cell lines may be generated using genetic stratification of patient lines, along with the use of environmental and genetic risk factors to initiate disease onset

clearance in iPSC-derived cell lines from SAD patients is a key area for investigation to determine whether it may be a primary mechanism for the disease. Finally, despite better culture models and genetic stratification of SAD cell lines, it may be that the initiation of the disease requires additional environmental risk factors. The extent to which susceptibility genes interact with each other and with environmental factors may provide further clues to aetiology. Therefore, we propose that the combined use of specific environmental risk factors in cell lines susceptible to such specific changes, based on genetic stratification, may be able to drive $\mathrm{SAD}$ onset.

Acknowledgements We gratefully acknowledge the financial support of the Dr. Donald Dean Fund for Dementia Research, The University of Manchester and the Medical Research Council (MR/N013255/1, MR/M024997/1 and MC_PC_16033).

\section{Compliance with Ethical Standards}

Conflict of interest The authors have no conflict of interest to declare. 
Open Access This article is distributed under the terms of the Creative Commons Attribution 4.0 International License (http://creativeco mmons.org/licenses/by/4.0/), which permits unrestricted use, distribution, and reproduction in any medium, provided you give appropriate credit to the original author(s) and the source, provide a link to the Creative Commons license, and indicate if changes were made.

\section{References}

1. Hardy JA, Higgins GA (1992) Alzheimer's disease: the amyloid cascade hypothesis. Science 256(5054):184-185

2. Selkoe DJ, Hardy J (2016) The amyloid hypothesis of Alzheimer's disease at 25 years. EMBO Mol Med 8(6):595-608. https ://doi.org/10.15252/emmm.201606210

3. Kondo T, Asai M, Tsukita K, Kutoku Y, Ohsawa Y, Sunada Y, Imamura K, Egawa N, Yahata N, Okita K, Takahashi K, Asaka I, Aoi T, Watanabe A, Watanabe K, Kadoya C, Nakano R, Watanabe D, Maruyama K, Hori O, Hibino S, Choshi T, Nakahata T, Hioki H, Kaneko T, Naitoh M, Yoshikawa K, Yamawaki S, Suzuki S, Hata R, Ueno S, Seki T, Kobayashi K, Toda T, Murakami K, Irie K, Klein WL, Mori H, Asada T, Takahashi R, Iwata N, Yamanaka S, Inoue H (2013) Modeling Alzheimer's disease with iPSCs reveals stress phenotypes associated with intracellular Abeta and differential drug responsiveness. Cell Stem Cell 12(4):487-496. https://doi.org/10.1016/j.stem.2013.01.009

4. Ulrich JD, Ulland TK, Colonna M, Holtzman DM (2017) Elucidating the Role of TREM2 in Alzheimer's Disease. Neuron 94(2):237-248. https://doi.org/10.1016/j.neuron.2017.02.042

5. Jonsson T, Stefansson H, Steinberg S, Jonsdottir I, Jonsson PV, Snaedal J, Bjornsson S, Huttenlocher J, Levey AI, Lah JJ, Rujescu D, Hampel H, Giegling I, Andreassen OA, Engedal K, Ulstein I, Djurovic S, Ibrahim-Verbaas C, Hofman A, Ikram MA, van Duijn CM, Thorsteinsdottir U, Kong A, Stefansson K (2013) Variant of TREM2 associated with the risk of Alzheimer's disease. N Engl J Med 368(2):107-116. https://doi.org/10.1056/ NEJMoa1211103

6. Guerreiro R, Wojtas A, Bras J, Carrasquillo M, Rogaeva E, Majounie E, Cruchaga C, Sassi C, Kauwe JSK, Lupton MK, Ryten M, Brown K, Lowe J, Ridge PG, Hammer MB, Wakutani Y, Proitsi P, Newhouse S, Lohmann E, Erginel-Unaltuna N, Medway C, Hanagasi H, Troakes C, Gurvit H, Bilgic B, Al-Sarraj S, Benitez B, Cooper B, Carrell D, Emre M, Zou FG, Ma L, Murray ME, Dickson DW, Younkin S, Hazrati L, Petersen RC, Corcoran CD, Cai YF, Oliveira C, Ribeiro MH, Santana I, Tschanz JT, Gibbs JR, Norton MC, Kloszewska I, Mecocci P, Soininen H, Tsolaki M, Vellas B, Munger RG, Mann DMA, PickeringBrown S, Lovestone S, Beck J, Mead S, Collinge J, Parsons L, Pocock J, Morris JC, Revesz T, Lashley T, Fox NC, Rossor MN, Grenier-Boley B, Bellenguez C, Moskvina V, Sims R, Harold D, Williams J, Lambert JC, Amouyel P, Graff-Radford N, Goate A, Rademakers R, Morgan K, Powell J, St George-Hyslop P Singleton P, Hardy A, Consortium J, Consortium E, Consortium G, Group U AGA (2013) TREM2 variants in Alzheimer's disease. New Engl J Med 368(2):117-127. https://doi.org/10.1056/Nejmo a1211851

7. Raghavan N, Tosto G (2017) Genetics of Alzheimer's disease: the importance of polygenic and epistatic components. Curr Neurol Neurosci. https://doi.org/10.1007/s11910-017-0787-1

8. Arber C, Lovejoy C, Wray S (2017) Stem cell models of Alzheimer's disease: progress and challenges. Alzheimers Res Ther. https://doi.org/10.1186/s13195-017-0268-4

9. Bergstrom P, Agholme L, Nazir FH, Satir TM, Toombs J, Wellington H, Strandberg J, Bontell TO, Kvartsberg H, Holmstrom
M, Borestrom C, Simonsson S, Kunath T, Lindahl A, Blennow K, Hanse E, Portelius E, Wray S, Zetterberg H (2016) Amyloid precursor protein expression and processing are differentially regulated during cortical neuron differentiation. Sci Rep. https ://doi.org/10.1038/Srep29200

10. Muratore CR, Zhou C, Liao MC, Fernandez MA, Taylor WM, Lagomarsino VN, Pearse RV, Rice HC, Negri JM, He A, Srikanth P, Callahan DG, Shin T, Zhou M, Bennett DA, Noggle S, Love JC, Selkoe DJ, Young-Pearse TL (2017) Cell-type Dependent Alzheimer's Disease Phenotypes: Probing the Biology of Selective Neuronal Vulnerability. Stem Cell Rep 9(6):1868-1884. https://doi.org/10.1016/j.stemcr.2017.10.015

11. Israel MA, Yuan SH, Bardy C, Reyna SM, Mu YL, Herrera C, Hefferan MP, Van Gorp S, Nazor KL, Boscolo FS, Carson CT, Laurent LC, Marsala M, Gage FH, Remes AM, Koo EH, Goldstein LSB (2012) Probing sporadic and familial Alzheimer's disease using induced pluripotent stem cells. Nature 482(7384):216-220. https://doi.org/10.1038/nature10821

12. Ochalek A, Mihalik B, Avci HX, Chandrasekaran A, Teglasi A, Bock I, Lo Giudice M, Tancos Z, Molnar K, Laszlo L, Nielsen JE, Holst B, Freude K, Hyttel P, Kobolak J, Dinnyes A (2017) Neurons derived from sporadic Alzheimer's disease iPSCs reveal elevated TAU hyperphosphorylation, increased amyloid levels, and GSK3B activation. Alzheimers Res Ther. https://doi.org/10.1186/s13195-017-0317-z

13. Mawuenyega KG, Sigurdson W, Ovod V, Munsell L, Kasten T, Morris JC, Yarasheski KE, Bateman RJ (2010) Decreased clearance of CNS beta-amyloid in Alzheimer's disease. Science 330(6012):1774. https://doi.org/10.1126/science.11976 23

14. Arbel-Ornath M, Hudry E, Eikermann-Haerter K, Hou S, Gregory JL, Zhao LZ, Betensky RA, Frosch MP, Greenberg SM, Bacskai BJ (2013) Interstitial fluid drainage is impaired in ischemic stroke and Alzheimer's disease mouse models. Acta Neuropathol 126(3):353-364. https://doi.org/10.1007/s00401-013-1145-2

15. Saido T, Leissring MA (2012) Proteolytic Degradation of Amyloid beta-Protein. Csh Perspect Med. https://doi.org/10.1101/ cshperspect.a006379

16. Pickford F, Masliah E, Britschgi M, Lucin K, Narasimhan R, Jaeger PA, Small S, Spencer B, Rockenstein E, Levine B, WyssCoray $\mathrm{T}$ (2008) The autophagy-related protein beclin 1 shows reduced expression in early Alzheimer disease and regulates amyloid beta accumulation in mice. J Clin Invest 118(6):21902199. https://doi.org/10.1172/JCI33585

17. Salminen A, Kaarniranta K, Kauppinen A, Ojala J, Haapasalo A, Soininen H, Hiltunen M (2013) Impaired autophagy and APP processing in Alzheimer's disease: The potential role of Beclin 1 interactome. Prog Neurobiol 106:33-54. https://doi. org/10.1016/j.pneurobio.2013.06.002

18. Bachmeier C, Paris D, Beaulieu-Abdelahad D, Mouzon B, Mullan M, Crawford F (2013) A Multifaceted Role for apoE in the Clearance of Beta-Amyloid across the Blood-Brain Barrier. Neurodegener Dis 11(1):13-21. https://doi.org/10.1159/000337231

19. Jiang Q, Lee CY, Mandrekar S, Wilkinson B, Cramer P, Zelcer N, Mann K, Lamb B, Willson TM, Collins JL, Richardson JC, Smith JD, Comery TA, Riddell D, Holtzman DM, Tontonoz P, Landreth GE (2008) ApoE promotes the proteolytic degradation of Abeta. Neuron 58(5):681-693. https://doi.org/10.1016/j.neuro n.2008.04.010

20. Tarasoff-Conway JM, Carare RO, Osorio RS, Glodzik L, Butler T, Fieremans E, Axel L, Rusinek H, Nicholson C, Zlokovic BV, Frangione B, Blennow K, Menard J, Zetterberg H, Wisniewski T, de Leon MJ (2015) Clearance systems in the brain-implications for Alzheimer disease. Nat Rev Neurol 11(8):457-470. https:// doi.org/10.1038/nrneurol.2015.119 
21. Sweeney MD, Sagare AP, Zlokovic BV (2018) Blood-brain barrier breakdown in Alzheimer disease and other neurodegenerative disorders. Nat Rev Neurol 14(3):133-150. https://doi. org/10.1038/nrneurol.2017.188

22. Yagi T, Ito D, Okada Y, Akamatsu W, Nihei Y, Yoshizaki T, Yamanaka S, Okano H, Suzuki N (2011) Modeling familial Alzheimer's disease with induced pluripotent stem cells. Hum Mol Genet 20(23):4530-4539. https://doi.org/10.1093/hmg/ddr394

23. Shi YC, Kirwan P, Livesey FJ (2012) Directed differentiation of human pluripotent stem cells to cerebral cortex neurons and neural networks. Nat Protoc 7(10):1836-1846. https://doi. org/10.1038/nprot.2012.116

24. Moore S, Evans LD, Andersson T, Portelius E, Smith J, Dias TB, Saurat N, McGlade A, Kirwan P, Blennow K, Hardy J, Zetterberg H, Livesey FJ (2015) APP metabolism regulates tau proteostasis in human cerebral cortex neurons. Cell Rep 11(5):689-696. https://doi.org/10.1016/j.celrep.2015.03.068

25. Woodruff G, Young Jessica E, Martinez Fernando J, Buen F, Gore A, Kinaga J, Li Z, Yuan Shauna H, Zhang K, Goldstein Lawrence SB (2013) The presenilin-1 $\Delta$ E9 mutation results in reduced $\gamma$-secretase activity, but not total loss of PS1 function, in Isogenic human stem cells. Cell Rep 5(4):974-985. https:// doi.org/10.1016/j.celrep.2013.10.018

26. Raja WK, Mungenast AE, Lin YT, Ko T, Abdurrob F, Seo J, Tsai LH (2016) Self-Organizing 3D Human Neural Tissue Derived from Induced Pluripotent Stem Cells Recapitulate Alzheimer's Disease Phenotypes. PLoS ONE. https://doi. org/10.1371/journal.pone.0161969

27. Ovchinnikov DA, Korn O, Virshup I, Wells CA, Wolvetang EJ (2018) The Impact of APP on Alzheimer-like Pathogenesis and Gene Expression in Down Syndrome iPSC-Derived Neurons. Stem Cell Rep 11(1):32-42. https://doi.org/10.1016/j.stemc r.2018.05.004

28. Hossini AM, Megges M, Prigione A, Lichtner B, Toliat MR, Wruck W, Schroter F, Nuernberg P, Kroll H, Makrantonaki E, Zouboulis CC, Adjaye J (2015) Induced pluripotent stem cell-derived neuronal cells from a sporadic Alzheimer's disease donor as a model for investigating $\mathrm{AD}$-associated gene regulatory networks. 2015). BMC Genomics 16:84. https:// doi.org/10.1186/S12864-015-1537-X

29. Birnbaum JH, Wanner D, Gietl AF, Saake A, Kundig TM, Hock C, Nitsch RM, Tackenberg C (2018) Oxidative stress and altered mitochondrial protein expression in the absence of amyloid-beta and tau pathology in iPSC-derived neurons from sporadic Alzheimer's disease patients. Stem Cell Res 27:121-130. https://doi.org/10.1016/j.scr.2018.01.019

30. Young JE, Boulanger-Weill J, Williams DA, Woodruff G, Buen F, Revilla AC, Herrera C, Israel MA, Yuan SH, Edland SD, Goldstein LSB (2015) Elucidating molecular phenotypes caused by the SORL1 Alzheimer's disease genetic risk factor using human induced pluripotent stem cells. Cell stem cell 16(4):373-385. https://doi.org/10.1016/j.stem.2015.02.004

31. Nieweg K, Andreyeva A, van Stegen B, Tanriover G, Gottmann K (2015) Alzheimer's disease-related amyloid-beta induces synaptotoxicity in human iPS cell-derived neurons. Cell Death Dis. https://doi.org/10.1038/Cddis.2015.72

32. Armijo E, Gonzalez C, Shahnawaz M, Flores A, Davis B, Soto C (2017) Increased susceptibility to A beta toxicity in neuronal cultures derived from familial Alzheimer's disease (PSEN1-A246E) induced pluripotent stem cells. Neurosci Lett 639:74-81. https://doi.org/10.1016/j.neulet.2016.12.060

33. Patani R, Lewis PA, Trabzuni D, Puddifoot CA, Wyllie DJA, Walker R, Smith C, Hardingham GE, Weale M, Hardy J, Chandran S, Ryten M (2012) Investigating the utility of human embryonic stem cell-derived neurons to model ageing and neurodegenerative disease using whole-genome gene expression and splicing analysis. J Neurochem 122(4):738-751. https:// doi.org/10.1111/j.1471-4159.2012.07825.x

34. Miller JD, Ganat YM, Kishinevsky S, Bowman RL, Liu B, Tu EY, Mandal PK, Vera E, Shim JW, Kriks S, Taldone T, Fusaki N, Tomishima MJ, Krainc D, Milner TA, Rossi DJ, Studer L (2013) Human iPSC-based modeling of late-onset disease via progerin-induced aging. Cell stem cell 13(6):691-705. https:// doi.org/10.1016/j.stem.2013.11.006

35. Petrini S, Borghi R, D’Oria V, Restaldi F, Moreno S, Novelli A, Bertini E, Compagnucci C (2017) Aged induced pluripotent stem cell (iPSCs) as a new cellular model for studying premature aging. Aging 9(5):1453-1469. https://doi.org/10.18632/ aging. 101248

36. Livesey FJ (2012) Stem cell models of Alzheimer's disease and related neurological disorders. Alzheimers Res Ther. https://doi. org/10.1186/Alzrt147

37. Hu WX, Qiu BL, Guan WQ, Wang QY, Wang M, Li W, Gao LF, Shen L, Huang Y, Xie GC, Zhao HZ, Jin Y, Tang BS, Yu YC, Zhao J, Pei G (2015) Direct conversion of normal and Alzheimer's disease human fibroblasts into neuronal cells by small molecules. Cell Stem Cell 17(2):204-212. https://doi.org/10.1016/j. stem.2015.07.006

38. Mertens J, Paquola ACM, Ku MC, Hatch E, Bohnke L, Ladjevardi S, McGrath S, Campbell B, Lee H, Herdy JR, Goncalves JT, Toda T, Kim Y, Winkler J, Yao J, Hetzer MW, Gage FH (2015) Directly reprogrammed human neurons retain aging-associated transcriptomic signatures and reveal age-related nucleocytoplasmic defects. Cell Stem Cell 17(6):705-718. https://doi. org/10.1016/j.stem.2015.09.001

39. Pasca AM, Sloan SA, Clarke LE, Tian Y, Makinson CD, Huber N, Kim CH, Park JY, O'Rourke NA, Nguyen KD, Smith SJ, Huguenard JR, Geschwind DH, Barres BA, Pasca SP (2015) Functional cortical neurons and astrocytes from human pluripotent stem cells in 3D culture. Nat Methods 12(7):671. https:// doi.org/10.1038/Nmeth.3415

40. Ghaffari LT, Starr A, Nelson AT, Sattler R (2018) Representing diversity in the dish: using patient-derived in vitro models to recreate the heterogeneity of neurological disease. Front NeurosciSwitz. https://doi.org/10.3389/Fnins.2018.00056

41. Sposito T, Preza E, Mahoney CJ, Seto-Salvia N, Ryan NS, Morris HR, Arber C, Devine MJ, Houlden H, Warner TT, Bushell TJ, Zagnoni M, Kunath T, Livesey FJ, Fox NC, Rossor MN, Hardy J, Wray S (2015) Developmental regulation of tau splicing is disrupted in stem cell-derived neurons from frontotemporal dementia patients with the $10+16$ splice-site mutation in MAPT. Hum Mol Genet 24(18):5260-5269. https://doi.org/10.1093/hmg/ ddv246

42. Wang C, Ward ME, Chen R, Liu K, Tracy TE, Chen X, Xie M, Sohn PD, Ludwig C, Meyer-Franke A, Karch CM, Ding S, Gan L (2017) Scalable production of iPSC-derived human neurons to identify tau-lowering compounds by high-content screening. Stem Cell Rep 9(4):1221-1233. https://doi.org/10.1016/j.stemc r.2017.08.019

43. von Bartheld CS, Bahney J, Herculano-Houzel S (2016) The search for true numbers of neurons and glial cells in the human brain: a review of 150 years of cell counting. J Comp Neurol 524(18):3865-3895. https://doi.org/10.1002/cne.24040

44. Dzamba D, Harantova L, Butenko O, Anderova M (2016) Glial Cells - The Key Elements of Alzheimer's Disease. Curr Alzheimer Res 13(8):894-911. https://doi.org/10.2174/1567205013 666160129095924

45. Pihlaja R, Koistinaho J, Kauppinen R, Sandholm J, Tanila H, Koistinaho M (2011) Multiple cellular and molecular mechanisms are involved in human Abeta clearance by transplanted adult astrocytes. Glia 59(11):1643-1657. https://doi.org/10.1002/ glia.21212 
46. Mulder SD, Nielsen HM, Blankenstein MA, Eikelenboom P, Veerhuis R (2014) Apolipoproteins E and J interfere with amyloid-beta uptake by primary human astrocytes and microglia in vitro. Glia 62(4):493-503. https://doi.org/10.1002/glia.22619

47. Oksanen M, Petersen AJ, Naumenko N, Puttonen K, Lehtonen S, Gubert Olive M, Shakirzyanova A, Leskela S, Sarajarvi T, Viitanen M, Rinne JO, Hiltunen M, Haapasalo A, Giniatullin R, Tavi P, Zhang SC, Kanninen KM, Hamalainen RH, Koistinaho J (2017) PSEN1 Mutant iPSC-Derived Model Reveals Severe Astrocyte Pathology in Alzheimer's Disease. Stem Cell Rep 9(6):1885-1897. https://doi.org/10.1016/j.stemcr.2017.10.016

48. Liao MC, Muratore CR, Gierahn TM, Sullivan SE, Srikanth P, De Jager PL, Love JC, Young-Pearse TL (2016) Single-cell detection of secreted abeta and sAPPalpha from human IPSCderived neurons and astrocytes. J Neurosci 36(5):1730-1746. https://doi.org/10.1523/JNEUROSCI.2735-15.2016

49. Krencik R, Zhang SC (2011) Directed differentiation of functional astroglial subtypes from human pluripotent stem cells. Nat Protoc 6(11):1710-1717. https://doi.org/10.1038/nprot.2011.405

50. Emdad L, D'Souza SL, Kothari HP, Qadeer ZA, Germano IM (2012) Efficient differentiation of human embryonic and induced pluripotent stem cells into functional astrocytes. Stem Cells Dev 21(3):404-410. https://doi.org/10.1089/scd.2010.0560

51. Roybon L, Lamas NJ, Garcia-Diaz A, Yang EJ, Sattler R, Jackson-Lewis V, Kim YA, Kachel CA, Rothstein JD, Przedborski S, Wichterle H, Henderson CE (2013) Human stem cell-derived spinal cord astrocytes with defined mature or reactive phenotypes. Cell Rep 4(5):1035-1048. https://doi.org/10.1016/j.celre p.2013.06.021

52. Shaltouki A, Peng J, Liu QY, Rao MS, Zeng XM (2013) Efficient generation of astrocytes from human pluripotent stem cells in defined conditions. Stem Cells 31(5):941-952. https://doi. org/10.1002/stem.1334

53. Zhang ZN, Freitas BC, Qian H, Lux J, Acab A, Trujillo CA, Herai RH, Huu VAN, Wen JH, Joshi-Barr S, Karpiak JV, Engler AJ, Fu XD, Muotri AR, Almutairi A (2016) Layered hydrogels accelerate iPSC-derived neuronal maturation and reveal migration defects caused by $\mathrm{MeCP} 2$ dysfunction. PNAS 113(12):3185-3190. https://doi.org/10.1073/pnas.1521255113

54. Caiazzo M, Giannelli S, Valente P, Lignani G, Carissimo A, Sessa A, Colasante G, Bartolomeo R, Massimino L, Ferroni S, Settembre C, Benfenati F, Broccoli V (2015) Direct conversion of fibroblasts into functional astrocytes by defined transcription factors. Stem Cell Rep 4(1):25-36. https://doi.org/10.1016/j. stemcr.2014.12.002

55. Jones VC, Atkinson-Dell R, Verkhratsky A, Mohamet L (2017) Aberrant iPSC-derived human astrocytes in Alzheimer's disease. Cell death disease 8(3):e2696. https://doi.org/10.1038/cddis .2017 .89

56. Lin YT, Seo J, Gao F, Feldman HM, Wen HL, Penney J, Cam HP, Gjoneska E, Raja WK, Cheng J, Rueda R, Kritskiy O, Abdurrob F, Peng ZY, Milo B, Yu CJ, Elmsaouri S, Dey D, Ko T, Yankner BA, Tsai LH (2018) APOE4 causes widespread molecular and cellular alterations associated with Alzheimer's disease phenotypes in human iPSC-derived brain cell types. Neuron 98(6):1141. https://doi.org/10.1016/j.neuron.2018.05.008

57. Zhao J, Davis MD, Martens YA, Shinohara M, Graff-Radford NR, Younkin SG, Wszolek ZK, Kanekiyo T, Bu G (2017) APOE epsilon 4/epsilon 4 diminishes neurotrophic function of human iPSC-derived astrocytes. Hum Mol Genet 26(14):2690-2700. https://doi.org/10.1093/hmg/ddx155

58. Hickman SE, Allison EK, El Khoury J (2008) Microglial dysfunction and defective beta-amyloid clearance pathways in aging Alzheimer's disease mice. J Neurosci 28(33):8354-8360. https:// doi.org/10.1523/Jneurosci.0616-08.2008
59. Liu ZQ, Condello C, Schain A, Harb R, Grutzendler J (2010) CX3CR1 in microglia regulates brain amyloid deposition through selective protofibrillar amyloid-beta phagocytosis. J Neurosci 30(50):17091-17101. https://doi.org/10.1523/Jneur osci.4403-10.2010

60. Krasemann S, Madore C, Cialic R, Baufeld C, Calcagno N, El Fatimy R, Beckers L, O’Loughlin E, Xu Y, Fanek Z, Greco DJ, Smith ST, Tweet G, Humulock Z, Zrzavy T, Conde-Sanroman P, Gacias M, Weng ZP, Chen H, Tjon E, Mazaheri F, Hartmann K, Madi A, Ulrich JD, Glatzel M, Worthmann A, Heeren J, Budnik B, Lemere C, Ikezu T, Heppner FL, Litvak V, Holtzman DM, Lassmann H, Weiner HL, Ochando J, Haass C, Butovsky O (2017) The TREM2-APOE pathway drives the transcriptional phenotype of dysfunctional microglia in neurodegenerative diseases. Immunity 47(3):566. https://doi.org/10.1016/j.immun i. 2017.08 .008

61. Muffat J, Yuan BB, Mitalipoya M, Omer A, Corcoran S, Bakiasi G, Tsai LH, Aubourg P, Ransohoff RM, Jaenisch R (2016) Efficient derivation of microglia-like cells from human pluripotent stem cells. Nat Med 22(11):1358-1367. https://doi.org/10.1038/ nm. 4189

62. Abud EM, Ramirez RN, Martinez ES, Healy LM, Nguyen CHH, Newman SA, Yeromin AV, Scarfone VM, Marsh SE, Fimbres C, Caraway CA, Fote GM, Madany AM, Agrawal A, Kayed R, Gylys KH, Cahalan MD, Cummings BJ, Antel JP, Mortazavi A, Carson MJ, Poon WW, Blurton-Jones M (2017) iPSC-derived human microglia-like cells to study neurological diseases. Neuron 94(2):278. https://doi.org/10.1016/j.neuron.2017.03.042

63. Pandya H, Shen MJ, Ichikawa DM, Sedlock AB, Choi Y, Johnson KR, Kim G, Brown MA, Elkahloun AG, Maric D, Sweeney CL, Gossa S, Malech HL, McGavern DB, Park JK (2017) Differentiation of human and murine induced pluripotent stem cells to microglia-like cells. Nat Neurosci 20(5):753. https://doi. org/10.1038/nn.4534

64. Haenseler W, Sansom SN, Buchrieser J, Newey SE, Moore CS, Nicholls FJ, Chintawar S, Schnell C, Antel JP, Allen ND, Cader MZ, Wade-Martins R, James WS, Cowley SA (2017) A highly efficient human pluripotent stem cell microglia model displays a neuronal-co-culture-specific expression profile and inflammatory response. Stem Cell Rep 8(6):1727-1742. https://doi. org/10.1016/j.stemcr.2017.05.017

65. Brownjohn PW, Smith J, Solanki R, Lohmann E, Houlden H, Hardy J, Dietmann S, Livesey FJ (2018) Functional studies of missense TREM2 mutations in human stem cell-derived microglia. Stem Cell Rep 10(4):1294-1307. https://doi.org/10.1016/j. stemcr.2018.03.003

66. Tognatta R, Miller RH (2016) Contribution of the oligodendrocyte lineage to CNS repair and neurodegenerative pathologies. Neuropharm 110:539-547. https://doi.org/10.1016/j.neuropharm .2016.04.026

67. Roher AE, Weiss N, Kokjohn TA, Kuo YM, Kalback W, Anthony J, Watson D, Luehrs DC, Sue L, Walker D, Emmerling M, Goux W, Beach T (2002) Increased A beta peptides and reduced cholesterol and myelin proteins characterize white matter degeneration in Alzheimer's disease. Biochemistry 41(37):11080-11090. https://doi.org/10.1021/Bi026173d

68. Jantaratnotai N, Ryu JK, Kim SU, McLarnon JG (2003) Amyloid beta peptide-induced corpus callosum damage and glial activation in vivo. Neuroreport 14(11):1429-1433. https://doi. org/10.1097/01.wnr.000008609747480.a0

69. Nielsen HM, Ek D, Avdic U, Orbjorn C, Hansson O, Netherlands Brain B, Veerhuis R, Rozemuller AJ, Brun A, Minthon L, Wennstrom M (2013) NG2 cells, a new trail for Alzheimer's disease mechanisms? Acta Neuropathol Commun 1:7. https:// doi.org/10.1186/2051-5960-1-7 
70. Czepiel M, Balasubramaniyan V, Schaafsma W, Stancic M, Mikkers H, Huisman C, Boddeke E, Copray S (2011) Differentiation of induced pluripotent stem cells into functional oligodendrocytes. Glia 59(6):882-892. https://doi.org/10.1002/glia.21159

71. Livesey MR, Magnani D, Cleary EM, Vasistha NA, James OT, Selvaraj BT, Burr K, Story D, Shaw CE, Kind PC, Hardingham GE, Wyllie DJA, Chandran S (2016) Maturation and electrophysiological properties of human pluripotent stem cell-derived oligodendrocytes. Stem Cells 34(4):1040-1053. https://doi. org/10.1002/stem.2273

72. Ehrlich M, Mozafari S, Glatza M, Starost L, Velychko S, Hallmann AL, Cui QL, Schambach A, Kim KP, Bachelin C, Marteyn A, Hargus G, Johnson RM, Antel J, Sterneckert J, Zaehres H, Scholer HR, Evercooren B-V, Kuhlmann A T (2017) Rapid and efficient generation of oligodendrocytes from human induced pluripotent stem cells using transcription factors. PNAS 114(11):E2243-E2252. https://doi.org/10.1073/pnas.16144 12114

73. Ladecola $C$ (2017) The neurovascular unit coming of age: a journey through neurovascular coupling in health and disease. Neuron 96(1):17-42. https://doi.org/10.1016/j.neuron.2017.07.030

74. Love S, Miners JS (2015) White matter hypoperfusion and damage in dementia: post-mortem assessment. Brain Pathol 25(1):99-107. https://doi.org/10.1111/bpa.12223

75. Lippmann ES, Azarin SM, Kay JE, Nessler RA, Wilson HK, Al-Ahmad A, Palecek SP, Shusta EV (2012) Derivation of bloodbrain barrier endothelial cells from human pluripotent stem cells. Nat Biotechnol 30(8):783-791. https://doi.org/10.1038/nbt.2247

76. Cheung C, Bernardo AS, Trotter MWB, Pedersen RA, Sinha S (2012) Generation of human vascular smooth muscle subtypes provides insight into embryological origin-dependent disease susceptibility. Nat Biotechnol 30(2):165-173. https://doi. org/10.1038/nbt.2107

77. Appelt-Menzel A, Cubukova A, Gunther K, Edenhofer F, Piontek J, Krause G, Stuber T, Walles H, Neuhaus W, Metzger M (2017) Establishment of a human blood-brain barrier co-culture model mimicking the neurovascular unit using induced pluri- and multipotent stem cells. Stem Cell Rep 8(4):894-906. https://doi. org/10.1016/j.stemcr.2017.02.021

78. Potjewyd G, Moxon S, Wang T, Domingos M, Hooper NM (2018) Tissue engineering 3D neurovascular units: a biomaterials and bioprinting perspective. Trends in biotechnol 36(4):457-472. https://doi.org/10.1016/j.tibtech.2018.01.003

79. Dzyubenko E, Gottschling C, Faissner A (2016) Neuron-glia interactions in neural plasticity: contributions of neural extracellular matrix and perineuronal nets. Neural Plast. https://doi. org/10.1155/2016/5214961

80. Meyer K, Kaspar BK (2017) Glia-neuron interactions in neurological diseases: Testing non-cell autonomy in a dish. Brain Res 1656:27-39. https://doi.org/10.1016/j.brainres.2015.12.051

81. Kuijlaars J, Oyelami T, Diels A, Rohrbacher J, Versweyveld S, Meneghello G, Tuefferd M, Verstraelen P, Detrez JR, Verschuuren M, De Vos WH, Meert T, Peeters PJ, Cik M, Nuydens R, Brone B, Verheyen A (2016) Sustained synchronized neuronal network activity in a human astrocyte co-culture system. Sci Rep. https://doi.org/10.1038/Srep36529

82. Lancaster MA, Renner M, Martin CA, Wenzel D, Bicknell LS, Hurles ME, Homfray T, Penninger JM, Jackson AP, Knoblich JA (2013) Cerebral organoids model human brain development and microcephaly. Nature 501(7467):373. https://doi.org/10.1038/ nature 12517

83. Sasai Y (2013) Next-generation regenerative medicine: organogenesis from stem cells in 3D culture. Cell Stem Cell 12(5):520530. https://doi.org/10.1016/j.stem.2013.04.009
84. Qian XY, Nguyen HN, Song MM, Hadiono C, Ogden SC, Hammack C, Yao B, Hamersky GR, Jacob F, Zhong C, Yoon KJ, Jeang W, Lin L, Li YJ, Thakor J, Berg DA, Zhang C, Kang E, Chickering M, Nauen D, Ho CY, Wen ZX, Christian KM, Shi PY, Maher BJ, Wu H, Jin P, Tang HL, Song HJ, Ming GL (2016) Brain-region-specific organoids using mini-bioreactors for modeling ZIKV exposure. Cell 165(5):1238-1254. https:// doi.org/10.1016/j.cell.2016.04.032

85. Lee HK, Sanchez CV, Chen M, Morin PJ, Wells JM, Hanlon EB, Xia WM (2016) Three dimensional human neuro-spheroid model of Alzheimer's disease based on differentiated induced pluripotent stem cells. PLoS ONE. https://doi.org/10.1371/journ al.pone. 0163072

86. Chen M, Lee HK, Moo L, Hanlon E, Stein T, Xia W (2018) Common proteomic profiles of induced pluripotent stem cellderived three-dimensional neurons and brain tissue from Alzheimer patients. J Proteomics 182:21-33. https://doi.org/10.1016/j. jprot.2018.04.032

87. Choi SH, Kim YH, Hebisch M, Sliwinski C, Lee S, D’Avanzo C, Chen J, Hooli B, Asselin C, Muffat J, Klee JB, Zhang C, Wainger BJ, Peitz M, Kovacs DM, Woolf CJ, Wagner SL, Tanzi RE, Kim DY (2014) A three-dimensional human neural cell culture model of Alzheimer's disease. Nature 515(7526):274-278. https://doi. org/10.1038/nature13800

88. Kim YH, Choi SH, D’Avanzo C, Hebisch M, Sliwinski C, Bylykbashi E, Washicosky KJ, Klee JB, Brustle O, Tanzi RE, Kim DY (2015) A 3D human neural cell culture system for modeling Alzheimer's disease. Nat Protoc 10(7):985-1006. https:// doi.org/10.1038/nprot.2015.065

89. Medda X, Mertens L, Versweyveld S, Diels A, Barnham L, Bretteville A, Buist A, Verheyen A, Royaux I, Ebneth A, Cabrera-Socorro A (2016) Development of a scalable, highthroughput-compatible assay to detect tau aggregates using iPSC-derived cortical neurons maintained in a three-dimensional culture format. J Biomol Screen 21(8):804-815. https://doi. org/10.1177/1087057116638029

90. Zhang D, Pekkanen-Mattila M, Shahsavani M, Falk A, Teixeira AI, Herland A (2014) A 3D Alzheimer's disease culture model and the induction of P21-activated kinase mediated sensing in iPSC derived neurons. Biomaterials 35(5):1420-1428. https:// doi.org/10.1016/j.biomaterials.2013.11.028

91. Labour MN, Vigier S, Lerner D, Marcilhac A, Belamie E (2016) 3D compartmented model to study the neurite-related toxicity of Abeta aggregates included in collagen gels of adaptable porosity. Acta Biomater 37:38-49. https://doi.org/10.1016/j.actbi o.2016.04.001

92. Tang-Schomer MD, White JD, Tien LW, Schmitt LI, Valentin TM, Graziano DJ, Hopkins AM, Omenetto FG, Haydon PG, Kaplan DL (2014) Bioengineered functional brain-like cortical tissue. PNAS 111(38):13811-13816. https://doi.org/10.1073/ pnas. 1324214111

93. Li H, Wijekoon A, Leipzig ND (2012) 3D differentiation of neural stem cells in macroporous photopolymerizable hydrogel scaffolds. PLoS ONE. https://doi.org/10.1371/journal.pone.0048824

94. Han HW, Hsu SH (2017) Using 3D bioprinting to produce mini-brain. Neural Regen Res 12(10):1595-1596. https://doi. org/10.4103/1673-5374.217325

95. Espuny-Camacho I, Arranz AM, Fiers M, Snellinx A, Ando K, Munck S, Bonnefont J, Lambot L, Corthout N, Omodho L, Eynden EV, Radaelli E, Tesseur I, Wray S, Ebneth A, Hardy J, Leroy K, Brion JP, Vanderhaeghen P, De Strooper B (2017) Hallmarks of Alzheimer's disease in stem-cell-derived human neurons transplanted into mouse brain. Neuron 93(5):1066. https ://doi.org/10.1016/j.neuron.2017.02.001 
96. Rouhani F, Kumasaka N, de Brito MC, Bradley A, Vallier L, Gaffney D (2014) Genetic background drives transcriptional variation in human induced pluripotent stem cells. PLoS Genet. https://doi.org/10.1371/journal.pgen.1004432

97. Burrows CK, Banovich NE, Pavlovic BJ, Patterson K, Gallego Romero I, Pritchard JK, Gilad Y (2016) Genetic variation, not cell type of origin, underlies the majority of identifiable regulatory differences in iPSCs. PLoS Genet 12(1):e1005793. https:// doi.org/10.1371/journal.pgen.1005793

98. Carcamo-Orive I, Hoffman GE, Cundiff P, Beckmann ND, D'Souza SL, Knowles JW, Patel A, Papatsenko D, Abbasi F, Reaven GM, Whalen S, Lee P, Shahbazi M, Henrion MYR, Zhu KX, Wang S, Roussos P, Schadt EE, Pandey G, Chang R, Quertermous T, Lemischka I (2017) Analysis of transcriptional variability in a large human iPSC library reveals genetic and nongenetic determinants of heterogeneity. Cell Stem Cell 20(4):518. https://doi.org/10.1016/j.stem.2016.11.005

99. Kilpinen H, Goncalves A, Leha A, Afzal V, Alasoo K, Ashford S, Bala S, Bensaddek D, Casale FP, Ulley OJC, Danecek P, Faulconbridge A, Harrison PW, Kathuria A, McCarthy D, McCarthy SA, Meleckyte R, Memari Y, Moens N, Soares F, Mann A, Streeter I, Agu CA, Alderton A, Nelson R, Harper S, Patel M, White A, Patel SR, Clarke L, Halai R, Kirton CM, KolbKokocinski A, Beales P, Birney E, Danovi D, Lamond AI, Ouwehand WH, Vallier L, Watt FM, Durbin R, Stegle O, Gaffney DJ (2017) Common genetic variation drives molecular heterogeneity in human iPSCs. Nature 546(7658):370. https://doi.org/10.1038/ nature 22403

100. DeBoever C, Li H, Jakubosky D, Benaglio P, Reyna J, Olson KM, Huang H, Biggs W, Sandoval E, D’Antonio M, Jepsen K, Matsui H, Arias A, Ren B, Nariai N, Smith EN, D'Antonio-Chronowska A, Farley EK, Frazer KA (2017) Large-scale profiling reveals the influence of genetic variation on gene expression in human induced pluripotent stem cells. Cell Stem Cell 20(4):533. https ://doi.org/10.1016/j.stem.2017.03.009

101. Warren CR, O'Sullivan JF, Friesen M, Becker CE, Zhang XL, Liu PC, Wakabayashi Y, Morningstar JE, Shi X, Choi J, Xia F, Peters DT, Florido MHC, Tsankov AM, Duberow E, Comisar L, Shay J, Jiang X, Meissner A, Musunuru K, Kathiresan S, Daheron L, Zhu J, Gerszten RE, Deo RC, Vasan RS, O'Donnell CJ, Cowan CA (2017) Induced pluripotent stem cell differentiation enables functional validation of GWAS variants in metabolic disease. Cell Stem Cell 20(4):547. https://doi.org/10.1016/j. stem.2017.01.010

102. Pashos EE, Park Y, Wang X, Raghavan A, Yang WL, Abbey D, Peters DT, Arbelaez J, Hernandez M, Kuperwasser N, Li WJ, Lian ZR, Liu Y, Lv WJ, Lytle-Gabbin SL, Marchadier DH, Rogov P, Shi JT, Slovik KJ, Stylianou IM, Wang L, Yan RL, Zhang XL, Kathiresan S, Duncan SA, Mikkelsen TS, Morrisey EE, Rader DJ, Brown CD, Musunuru K (2017) Large, diverse population cohorts of hiPSCs and derived hepatocyte-like cells reveal functional genetic variation at blood lipid-associated loci. Cell Stem Cell 20(4):558. https://doi.org/10.1016/j. stem.2017.03.017

103. Ortiz-Virumbrales M, Moreno CL, Kruglikov I, Marazuela P, Sproul A, Jacob S, Zimmer M, Paull D, Zhang B, Schadt EE, Ehrlich ME, Tanzi RE, Arancio O, Noggle S, Gandy S (2017) CRISPR/Cas9-correctable mutation-related molecular and physiological phenotypes in iPSC-derived Alzheimer's PSEN2(N141I) neurons. Acta Neuropathol Commun 5. https://doi.org/10.1186/ s40478-017-0475-z

104. Pires C, Schmid B, Petraeus C, Poon A, Nimsanor N, Nielsend TT, Waldemar G, Hjermind LE, Nielsen JE, Hyttel P, Freude KK (2016) Generation of a gene-corrected isogenic control cell line from an Alzheimer's disease patient iPSC line carrying a A79V mutation in PSEN1. Stem Cell Res 17(2):285-288. https://doi. org/10.1016/j.scr.2016.08.002

105. Poon A, Schmid B, Pires C, Nielsen TT, Hjermind LE, Nielsen JE, Holst B, Hyttel P, Freude KK (2016) Generation of a genecorrected isogenic control hiPSC line derived from a familial Alzheimer's disease patient carrying a L150P mutation in presenilin 1. Stem Cell Res 17(3):466-469. https://doi.org/10.1016/j. scr.2016.09.018

106. Paquet D, Kwart D, Chen A, Sproul A, Jacob S, Teo S, Olsen KM, Gregg A, Noggle S, Tessier-Lavigne M (2016) Efficient introduction of specific homozygous and heterozygous mutations using CRISPR/Cas9. Nature 533(7601):125. https://doi. org/10.1038/nature17664

107. Ihry RJ, Worringer KA, Salick MR, Frias E, Ho D, Theriault K, Kommineni S, Chen J, Sondey M, Ye CY, Randhawa R, Kulkarni T, Yang Z, McAllister G, Russ C, Reece-Hoyes J, Forrester W, Hoffman GR, Dolmetsch R, Kaykas A (2018) p53 inhibits CRISPR-Cas9 engineering in human pluripotent stem cells. Nat Med 24(7):939. https://doi.org/10.1038/s41591-018-0050-6

108. Haapaniemi E, Botla S, Persson J, Schmierer B, Taipale J (2018) CRISPR-Cas9 genome editing induces a p53-mediated DNA damage response. Nat Med 24(7):927. https://doi.org/10.1038/ s41591-018-0049-z

109. Suh J, Choi SH, Romano DM, Gannon MA, Lesinski AN, Kim DY, Tanzi RE (2013) ADAM10 missense mutations potentiate beta-amyloid accumulation by impairing prodomain chaperone function. Neuron 80(2):385-401. https://doi.org/10.1016/j.neuro n.2013.08.035

110. Vardarajan BN, Zhang Y, Lee JH, Cheng R, Bohm C, Ghani M, Reitz C, Reyes-Dumeyer D, Shen Y, Rogaeva E, St GeorgeHyslop P, Mayeux R (2015) Coding mutations in SORL1 and Alzheimer disease. Ann Neurol 77(2):215-227. https://doi. org/10.1002/ana.24305

111. Tan MS, Yu JT, Tan L (2013) Bridging integrator 1 (BIN1): form, function, and Alzheimer's disease. Trends Mol Med 19(10):594-603. https://doi.org/10.1016/j.molmed.2013.06.004

112. Zhao Z, Sagare AP, Ma Q, Halliday MR, Kong P, Kisler K, Winkler EA, Ramanathan A, Kanekiyo T, Bu G, Owens NC, Rege SV, Si G, Ahuja A, Zhu D, Miller CA, Schneider JA, Maeda M, Maeda T, Sugawara T, Ichida JK, Zlokovic BV (2015) Central role for PICALM in amyloid-beta blood-brain barrier transcytosis and clearance. Nat Neurosci 18(7):978-987. https://doi. org/10.1038/nn.4025

113. Huang YWA, Zhou B, Wernig M, Sudhof TC (2017) ApoE2, ApoE3, and ApoE4 differentially stimulate APP transcription and A beta secretion. Cell 168(3):427. https://doi.org/10.1016/j. cell.2016.12.044

114. Zandl-Lang M, Fanaee-Danesh E, Sun Y, Albrecher NM, Gali CC, Cancar I, Kober A, Tam-Amersdorfer C, Stracke A, Storck SM, Saeed A, Stefulj J, Pietrzik CU, Wilson MR, Bjorkhem I, Panzenboeck U (2018) Regulatory effects of simvastatin and apoJ on APP processing and amyloid-beta clearance in blood-brain barrier endothelial cells. Biochim Biophys Acta 1863(1):40-60. https://doi.org/10.1016/j.bbalip.2017.09.008

115. Ito S, Ohtsuki S, Kamiie J, Nezu Y, Terasaki T (2007) Cerebral clearance of human amyloid-beta peptide (1-40) across the blood-brain barrier is reduced by self-aggregation and formation of low-density lipoprotein receptor-related protein-1 ligand complexes. J Neurochem 103(6):2482-2490. https://doi.org/10. 1111/j.1471-4159.2007.04938.x

116. Fu YH, Hsiao JHT, Paxinos G, Halliday GM, Kim WS (2016) ABCA7 mediates phagocytic clearance of amyloid-beta in the brain. J Alzheimers Dis 54(2):569-584. https://doi.org/10.3233/ Jad-160456 
117. Helisalmi S, Hiltunen M, Vepsalainen S, Iivonen S, Mannermaa A, Lehtovirta M, Koivisto AM, Alafuzoff I, Soininen H (2004) Polymorphisms in neprilysin gene affect the risk of Alzheimer's disease in Finnish patients. J Neurol Neurosurg Psychiatry 75(12):1746-1748. https://doi.org/10.1136/jnnp.2004.036574

118. Wang HZ, Bi R, Zhang DF, Li GD, Ma XH, Fang YR, Li T, Zhang C, Yao YG (2016) Neprilysin confers genetic susceptibility to Alzheimer's disease in Han Chinese. Mol Neurobiol 53(7):4883-4892. https://doi.org/10.1007/s12035-015-9411-z

119. Vepsalainen S, Parkinson M, Helisalmi S, Mannermaa A, Soininen H, Tanzi RE, Bertram L, Hiltunen M (2007) Insulindegrading enzyme is genetically associated with Alzheimer's disease in the Finnish population. J Med Genet 44 (9). https:// doi.org/10.1136/Jmg.2006.048470

120. Chen HK, Ji ZS, Dodson SE, Miranda RD, Rosenblum CI, Reynolds IJ, Freedman SB, Weisgraber KH, Huang Y, Mahley RW (2011) Apolipoprotein E4 domain interaction mediates detrimental effects on mitochondria and is a potential therapeutic target for Alzheimer disease. J Biol Chem 286(7):5215-5221. https:// doi.org/10.1074/jbc.M110.151084

121. Harris FM, Tesseur I, Brecht WJ, Xu Q, Mullendorff K, Chang SJ, Wyss-Coray T, Mahley RW, Huang YD (2004) Astroglial regulation of apolipoprotein E expression in neuronal cells-implications for Alzheimer's disease. J Biol Chem 279(5):3862-3868. https://doi.org/10.1074/jbc.M309475200

122. Mahoney-Sanchez L, Belaidi AA, Bush AI, Ayton S (2016) The Complex role of apolipoprotein E in Alzheimer's disease: an overview and update. J Mol Neurosci 60(3):325-335. https://doi. org/10.1007/s12031-016-0839-z

123. Duan LS, Bhattacharyya BJ, Belmadani A, Pan LL, Miller RJ, Kessler JA (2014) Stem cell derived basal forebrain cholinergic neurons from Alzheimer's disease patients are more susceptible to cell death. Mol Neurodegener. https://doi. org/10.1186/1750-1326-9-3

124. Wang CZ, Najm R, Xu Q, Jeong DE, Walker D, Balestra ME, Yoon SY, Yuan HD, Li G, Miller ZA, Miller BL, Malloy MJ, Huang YD (2018) Gain of toxic apolipoprotein E4 effects in human iPSC-derived neurons is ameliorated by a small-molecule structure corrector. Nat Med 24(5):647. https://doi.org/10.1038/ s41591-018-0004-Z

125. Zollo A, Allen Z, Rasmussen HF, Iannuzzi F, Shi Y, Larsen A, Maier TJ, Matrone C (2017) Sortilin-related receptor expression in human neural stem cells derived from Alzheimer's disease patients carrying the APOE epsilon 4 allele. Neural Plast. https ://doi.org/10.1155/2017/1892612

126. Gore A, Li Z, Fung HL, Young JE, Agarwal S, AntosiewiczBourget J, Canto I, Giorgetti A, Israel MA, Kiskinis E, Lee JH, Loh YH, Manos PD, Montserrat N, Panopoulos AD, Ruiz S, Wilbert ML, Yu J, Kirkness EF, Izpisua Belmonte JC, Rossi DJ, Thomson JA, Eggan K, Daley GQ, Goldstein LS, Zhang K (2011) Somatic coding mutations in human induced pluripotent stem cells. Nature 471(7336):63-67. https://doi.org/10.1038/ nature09805

127. Weller RO, Subash M, Preston SD, Mazanti I, Carare RO (2008) Perivascular drainage of amyloid-beta peptides from the brain and its failure in cerebral amyloid angiopathy and Alzheimer's disease. Brain Pathol 18(2):253-266. https://doi.org/10.111 1/j.1750-3639.2008.00133.x

128. Liu GH, Barkho BZ, Ruiz S, Diep D, Qu J, Yang SL, Panopoulos AD, Suzuki K, Kurian L, Walsh C, Thompson J, Boue S, Fung HL, Sancho-Martinez I, Zhang K, Yates J, Belmonte JCI (2011) Recapitulation of premature ageing with iPSCs from HutchinsonGilford progeria syndrome. Nature 472(7342):221-225. https:// doi.org/10.1038/nature09879

129. Zeldich E, Chen CD, Colvin TA, Bove-Fenderson EA, Liang J, Zhou TBT, Harris DA, Abraham CR (2014) The neuroprotective effect of klotho is mediated via regulation of members of the redox system. J Biol Chem 289(35):24700-24715. https://doi. org/10.1074/jbc.M114.567321

130. Bian A, Neyra JA, Zhan M, Hu MC (2015) Klotho, stem cells, and aging. Clin Interv Aging 10:1233-1243. https://doi. org/10.2147/Cia.S84978

131. Santos AL, Sinha S, Lindner AB (2018) The good, the bad, and the ugly of ROS: new insights on aging and aging-related diseases from eukaryotic and prokaryotic model organisms. Oxid Med Cell Longev. https://doi.org/10.1155/2018/1941285

132. Guo CY, Sun L, Chen XP, Zhang DS (2013) Oxidative stress, mitochondrial damage and neurodegenerative diseases. Neural Regen Res 8(21):2003-2014. https://doi.org/10.3969/j. issn.1673-5374.2013.21.009

133. Cheignon C, Tomas M, Bonnefont-Rousselot D, Faller P, Hureau C, Collin F (2018) Oxidative stress and the amyloid beta peptide in Alzheimer's disease. Redox Biol 14:450-464. https://doi. org/10.1016/j.redox.2017.10.014

134. Jonsson T, Stefansson H, Steinberg S, Jonsdottir I, Jonsson PV, Snaedal J, Bjornsson S, Huttenlocher J, Levey AI, Lah JJ, Rujescu D, Hampel H, Giegling I, Andreassen OA, Engedal K, Ulstein I, Djurovic S, Ibrahim-Verbaas C, Hofman A, Ikram MA, van Duijn CM, Thorsteinsdottir U, Kong A, Stefansson K (2013) Variant of TREM2 associated with the risk of Alzheimer's disease. New Engl J Med 368(2):107-116. https://doi.org/10.1056/ Nejmoa1211103

135. Roffe C (2002) Hypoxia and stroke. Age Ageing 31(suppl_2):10 12. https://doi.org/10.1093/ageing/31.suppl_2.10

136. Roberts EL, Chih CP, Rosenthal M (1997) Age-related changes in brain metabolism and vulnerability to anoxia. Adv Exp Med Biol 411:83-89

137. Sun X, He G, Qing H, Zhou W, Dobie F, Cai F, Staufenbiel M, Huang LE, Song W (2006) Hypoxia facilitates Alzheimer's disease pathogenesis by up-regulating BACE1 gene expression. PNAS 103(49):18727-18732. https://doi.org/10.1073/ pnas.0606298103

138. Li L, Zhang X, Yang D, Luo G, Chen S, Le W (2009) Hypoxia increases Abeta generation by altering beta- and gamma-cleavage of APP. Neurobiol Aging 30(7):1091-1098. https://doi. org/10.1016/j.neurobiolaging.2007.10.011

139. Zhang X, Zhou K, Wang R, Cui J, Lipton SA, Liao FF, Xu H, Zhang YW (2007) Hypoxia-inducible factor 1alpha (HIF1alpha)-mediated hypoxia increases BACE1 expression and betaamyloid generation. J Biol Chem 282(15):10873-10880. https:// doi.org/10.1074/jbc.M608856200

140. Villa Jennifer C, Chiu D, Brandes Alissa H, Escorcia Freddy E, Villa Carlos H, Maguire William F, Hu C-J, de Stanchina E, Simon MC, Sisodia Sangram S, Scheinberg David A, Li Y-M (2014) Nontranscriptional role of Hif- $1 \alpha$ in Activation of $\gamma$-secretase and notch signaling in breast cancer. Cell Rep 8(4):1077-1092. https://doi.org/10.1016/j.celrep.2014.07.028

141. Liu H, Qiu H, Yang J, Ni J, Le W (2016) Chronic hypoxia facilitates Alzheimer's disease through demethylation of $\gamma$-secretase by downregulating DNA methyltransferase $3 \mathrm{~b}$. Alzheimers Dement 12(2):130-143. https://doi.org/10.1016/j. jalz.2015.05.019

142. Guglielmotto M, Aragno M, Autelli R, Giliberto L, Novo E, Colombatto S, Danni O, Parola M, Smith MA, Perry G, Tamagno E, Tabaton M (2009) The up-regulation of BACE1 mediated by hypoxia and ischemic injury: role of oxidative stress and HIF1alpha. J Neurochem 108(4):1045-1056. https://doi.org/10.111 1/j.1471-4159.2008.05858.x

143. Fisk L, Nalivaeva NN, Boyle JP, Peers CS, Turner AJ (2007) Effects of hypoxia and oxidative stress on expression of neprilysin in human neuroblastoma cells and rat cortical neurones 
and astrocytes. Neurochem Res 32(10):1741-1748. https://doi. org/10.1007/s11064-007-9349-2

144. Nalivaeva NN, Fisk L, Kochkina EG, Plesneva SA, Zhuravin IA, Babusikova E, Dobrota D, Turner AJ (2004) Effect of hypoxia/ ischemia and hypoxic preconditioning/reperfusion on expression of some amyloid-degrading enzymes. Ann N Y Acad Sci 1035:21-33. https://doi.org/10.1196/annals.1332.002

145. Hiltunen M, Makinen P, Peraniemi S, Sivenius J, van Groen T, Soininen H, Jolkkonen J (2009) Focal cerebral ischemia in rats alters APP processing and expression of Abeta peptide degrading enzymes in the thalamus. Neurobiol Dis 35(1):103-113. https:// doi.org/10.1016/j.nbd.2009.04.009

146. Bulloj A, Leal MC, Xu H, Castano EM, Morelli L (2010) Insulindegrading enzyme sorting in exosomes: a secretory pathway for a key brain amyloid-beta degrading protease. J Alzheimer's Dis JAD 19(1):79-95. https://doi.org/10.3233/JAD-2010-1206

147. Yagishita S, Suzuki S, Yoshikawa K, Iida K, Hirata A, Suzuki M, Takashima A, Maruyama K, Hirasawa A, Awaji T (2017) Treatment of intermittent hypoxia increases phosphorylated tau in the hippocampus via biological processes common to aging. Mol Brain 10(1):2. https://doi.org/10.1186/s13041-016-0282-7

148. Yoshida Y, Takahashi K, Okita K, Ichisaka T, Yamanaka S (2009) Hypoxia enhances the generation of induced pluripotent stem cells. Cell Stem Cell 5(3):237-241. https://doi. org/10.1016/j.stem.2009.08.001

149. Santilli G, Lamorte G, Carlessi L, Ferrari D, Nodari LR, Binda E, Delia D, Vescovi AL, De Filippis L (2010) Mild hypoxia enhances proliferation and multipotency of human neural stem cells. PLoS ONE. https://doi.org/10.1371/journal.pone.0008575

150. Mung KL, Tsui YP, Tai EWY, Chan YS, Shum DKY, Shea GKH (2016) Rapid and efficient generation of neural progenitors from adult bone marrow stromal cells by hypoxic preconditioning. Stem Cell Res Ther. https://doi.org/10.1186/S13287-016-0409-X

151. White CS, Lawrence CB, Brough D, Rivers-Auty J (2017) Inflammasomes as therapeutic targets for Alzheimer's disease. Brain Pathol 27(2):223-234. https://doi.org/10.1111/bpa.12478

152. Liddelow SA, Barres B (2017) Reactive astrocytes: production, function, and therapeutic potential. Immunity 46(6):957-967. https://doi.org/10.1016/j.immuni.2017.06.006

153. Heneka MT, Carson MJ, El Khoury J, Landreth GE, Brosseron F, Feinstein DL, Jacobs AH, Wyss-Coray T, Vitorica J, Ransohoff RM, Herrup K, Frautschy SA, Finsen B, Brown GC, Verkhratsky A, Yamanaka K, Koistinaho J, Latz E, Halle A, Petzold GC, Town T, Morgan D, Shinohara ML, Perry VH, Holmes C, Bazan NG, Brooks DJ, Hunot S, Joseph B, Deigendesch N, Garaschuk O, Boddeke E, Dinarello CA, Breitner JC, Cole GM, Golenbock DT, Kummer MP (2015) Neuroinflammation in Alzheimer's disease. Lancet Neurol 14 (4):388-405. https://doi.org/10.1016/ S1474-4422(15)70016-5

154. Balez R, Steiner N, Engel M, Munoz SS, Lum JS, Wu Y, Wang D, Vallotton P, Sachdev P, O'Connor M, Sidhu K, Munch G, Ooi L (2016) Neuroprotective effects of apigenin against inflammation, neuronal excitability and apoptosis in an induced pluripotent stem cell model of Alzheimer's disease. Sci Rep 6:31450. https ://doi.org/10.1038/srep31450

155. Lumeng CN, Saltiel AR (2011) Inflammatory links between obesity and metabolic disease. J Clin Invest 121(6):2111-2117. https ://doi.org/10.1172/JCI57132

156. Cai DS, Liu TW (2012) Inflammatory cause of metabolic syndrome via brain stress and NF-kappa B. Aging 4(2):98-115. https ://doi.org/10.18632/Aging.100431

157. Schilling MA (2016) Unraveling Alzheimer's: making sense of the relationship between diabetes and Alzheimer's disease. J Alzheimers Dis 51(4):961-977. https://doi.org/10.3233/Jad-150980

158. Zhao LX, Teter B, Morihara T, Lim GP, Ambegaokar SS, Ubeda OJ, Frautschy SA, Cole GM (2004) Insulin-degrading enzyme as a downstream target of insulin receptor signaling cascade: implications for Alzheimer's disease intervention. J Neurosci 24(49):11120-11126. https://doi.org/10.1523/Jneur osci.2860-04.2004

159. Jolivalt CG, Hurford R, Lee CA, Dumaop W, Rockenstein E, Masliah E (2010) Type 1 diabetes exaggerates features of Alzheimer's disease in APP transgenic mice. Exp Neurol 223(2):422431. https://doi.org/10.1016/j.expneurol.2009.11.005

160. Swerdlow RH, Burns JM, Khan SM (2014) The Alzheimer's disease mitochondrial cascade hypothesis: progress and perspectives. Mol Basis Dis 1842(8):1219-1231. https://doi. org/10.1016/j.bbadis.2013.09.010

161. Esteras N, Rohrer JD, Hardy J, Wray S, Abramov AY (2017) Mitochondrial hyperpolarization in iPSC-derived neurons from patients of FTDP-17 with $10+16$ MAPT mutation leads to oxidative stress and neurodegeneration. Redox Biol 12:410-422. https://doi.org/10.1016/j.redox.2017.03.008

162. Imaizumi Y, Okada Y, Akamatsu W, Koike M, Kuzumaki N, Hayakawa H, Nihira T, Kobayashi T, Ohyama M, Sato S, Takanashi M, Funayama M, Hirayama A, Soga T, Hishiki T, Suematsu M, Yagi T, Ito D, Kosakai A, Hayashi K, Shouji M, Nakanishi A, Suzuki N, Mizuno Y, Mizushima N, Amagai M, Uchiyama Y, Mochizuki H, Hattori N, Okano H (2012) Mitochondrial dysfunction associated with increased oxidative stress and alpha-synuclein accumulation in PARK2 iPSC-derived neurons and postmortem brain tissue. Mol Brain. https://doi. org/10.1186/1756-6606-5-35

163. Chung SY, Kishinevsky S, Mazzulli JR, Graziotto J, Mrejeru A, Mosharov EV, Puspita L, Valiulahi P, Sulzer D, Milner TA, Taldone T, Krainc D, Studer L, Shim JW (2016) Parkin and PINK1 patient iPSC-derived midbrain dopamine neurons exhibit mitochondrial dysfunction and alpha-synuclein accumulation. Stem Cell Rep 7(4):664-677. https://doi.org/10.1016/j.stemc r.2016.08.012

164. Martin-Maestro P, Gargini R, Sproul AA, Garcia E, Anton LC, Noggle S, Arancio O, Avila J, Garcia-Escudero V (2017) Mitophagy failure in fibroblasts and iPSC-derived neurons of Alzheimer's disease-associated presenilin 1 mutation. Front Mol Neurosci. https://doi.org/10.3389/Fnmol.2017.00291 